\title{
Sedimentology and petrography of a lower Cambrian transgressive sequence: Altona Formation (Potsdam Group) in northeastern New York
}

\author{
Ryan Brink, Charlotte Mehrtens \& Henry Maguire
}

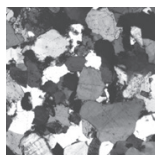

\begin{abstract}
The Altona Formation, the oldest unit in Potsdam Group, is a heterolithic shallow marine deposit recording fair weather and storm deposition in a marginal marine setting associated with the onlap of the Laurentian Craton in the latest early Cambrian (Olenellus Zone) to middle middle Cambrian (Bathyuriscus-Elrathina Zone). Six lithofacies are recognized within the Altona Formation including non-marine sheet flood, nearshore bay/estuary, and upper and middle shoreface. These lithofacies occur in the stratigraphy in response to relative sea level change and sediment supply. Onlap of Precambrian Grenville basement represents initial transgressive systems tract deposition which was succeeded by highstand deposition, and with it, diminished terrigenous input and the onset of carbonate deposition. Renewed input of terrigenous sand in the upper third of the Altona resulted in shoreline progradation followed by a second cycle of transgressive and highstand systems tract deposition. The overlying Ausable Formation marks the transition to falling sea level and onset of non-marine deposition. Analysis of gamma ray log data confirms that terrigenous sediment input varied through the stratigraphy, which is interpreted as a response to rising sea level trapping sediment on the coastal plain. Predominantly compositionally immature sandstone, the Altona also contains arenaceous dolostone, dolostone and silty shale. Modal analysis of the sandstones indicates an arkosic composition for the sandstones, with an accessory mineral suite including apatite, ilmenite, rutile, and zircon. This accessory suite, along with detrital zircon ages, indicates an Adirondack massif source rock. - Key words: Cambrian, Olenellus, Elhmaniella, sedimentology, shoreface, systems tracts, gamma ray log, Sauk II.
\end{abstract}

Brink, R., Mehrtens, C. \& Maguire, H. 2019. Sedimentology and petrography of a lower Cambrian transgressive sequence: Altona Formation (Potsdam Group) in northeastern New York. Bulletin of Geosciences 94(3), 369-388 (18 figures, 2 tables, appendix). Czech Geological Survey, Prague. ISSN 1214-1119. Manuscript received October 12 , 2018; accepted in revised form June 27, 2019; published online November 30, 2019; issued November 30, 2019.

Ryan Brink \& Charlotte Mehrtens, Department of Geology, University of Vermont, Burlington, VT 05405, USA; charlotte.mehrtens@uvm.edu • Henry Maguire, Department of Geosciences, University of Calgary, Calgary, Alberta, T2N 1 N4, Canada

As a result of recent revisions to the stratigraphic nomenclature and ages of the basal sandstone units that outcrop in the St. Lawrence lowlands and Champlain Valley of New York, Quebec, Ontario and Vermont, (e.g., Landing et al. 2009, Sanford \& Arnott 2010, Lowe et al. 2017) there is a need for detailed description and interpretation of the stratigraphy that records the onlap of the Laurentian Craton in the Cambrian. While Landing et al. (2009) identified fossils and generally described the Altona Formation as a shallow marine deposit, the greater detail of section measurement and description in this study permit more refined environmental interpretations. This study presents detailed compositional and sedimentologic descriptions and interpretation of the Altona Formation, the basal transgressive unit in the Cambrian sequence in the region northeast of the Adirondack Massif. We hope our data will shed light on regional paleogeographic questions, such as provenance and sediment transport patterns and regional correlations.

\section{Regional stratigraphy and geologic setting}

The Altona Formation outcrops within in the southwestern-most portion of the Quebec Basin (Fig. 1), a major reentrant in the rifted Laurentian margin, the main axis of which lay to the east in Vermont. The ocean affinity of latest Precambrian mafic volcanic rocks in southern Quebec and Vermont that form the basement beneath the Cambrian stratigraphy there confirm their tectonic significance, and radiometric dates of these units constrain rifting to 615 to $554(+10 /-8)$ Ma (Abdel-Rahman \& Kumarapeli 1999, Malka et al. 2000, Coish et al. 2012). The large-scale promontory-reentrant geometry of the rifted North American margin has long been known (e.g., Thomas 1977), however variation in the smaller-scale along-strike geometry that controlled thickness and facies of syn- and post-rift strata has only more recently been described (e.g., Cherichetti et al. 1998, Mehrtens \& Brink 2015). The tectonic and structural relationship between 


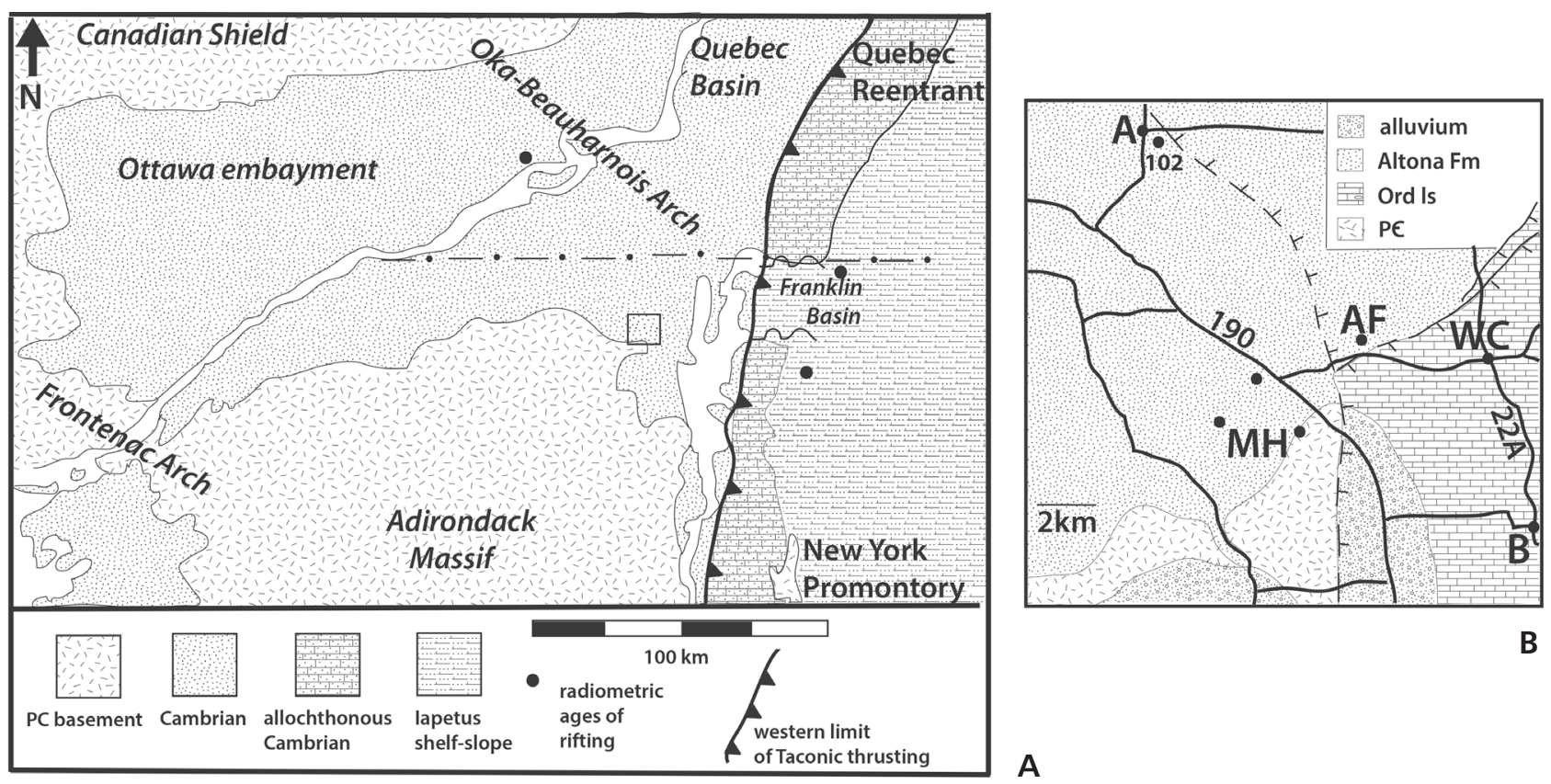

Figure 1. A - location of the study area and major physiographic and geologic features. Radiometric ages for MORB-affinity rift basalts are shown by dots. The location of the Franklin Basin in northernmost Vermont is indicated. - B - detailed geologic map of key outcrops used in this study to construct the composite stratigraphic column for the Altona Formation. Abbreviations: B - Beekmantown; A - Altona; WC - West Chazy; MH Murtaugh Hill; AF - Atwood Farm. The location of the fault shown is from Lowe (personal communication).

the Ottawa-Bonnechere Graben (Kay 1942), which lays to the north and west of the study area and the main axis of rifting to the east in Vermont is not clear. Improved understanding of possible links between the sedimentary succession in the western basin and the main Iapetus shelf margin in Vermont may help clarify this.

The paucity of body fossils in the Altona Formation make precise age determinations difficult, however better dated overlying strata (summarized in Hagadorn \& Belt 2008) provide constraints on its youngest possible age and radiometric dates on rift-related dikes intruding Adirondack basement provide a maximum age $\sim 590 \mathrm{Ma}$ but may be as young as $\sim 554 \mathrm{Ma}$ (Kumarapeli 1993).

Stratigraphic relationships in the Potsdam Group in New York and the Cambrian succession in Vermont are presented in Fig. 2. The stratigraphic nomenclature of the basal sedimentary sequence on the Laurentian Craton has been in revision for several years by stratigraphers (e.g., Clark 1966, Clark \& Lewis 1971, Sanford 2007, Lowe et al. 2017) and only a brief review is presented here. Historically, in New York the stratigraphic names "Ausable" and "Keeseville" Sandstones have been applied to the lower and upper members within the Potsdam Sandstone (e.g., Fisher 1955). Sanford's (2007) comprehensive synthesis of Cambrian stratigraphy in Ontario, Quebec and northern New York solidified the use of the term "Potsdam Group" to describe the genetically related package of Cambrian to Lower Ordovician strata in this region. In this scheme the Ausable and Keeseville Sandstones were elevated to formation status within the Potsdam Group. Most recently, Landing et al. (2009) described fragments of an Olenellid trilobite as well as specimens of Ehmaniella from a heterolithic unit which lies below the Ausable Sandstone. The discoveries of these fossils led Landing et al. (2009) to suggest that the older horizons should be recognized as a separate unit termed the Altona Formation. Sanford \& Arnott (2010) applied the name "Jericho Member" of the Ausable Formation for this same group of rocks but this study adopts the terminology suggested by Landing and his coworkers.

The fauna retrieved from the Altona by Landing et al. (2009) indicates an older age for the base of the Potsdam Group than previously recognized (no older than Series 2 of the Cambrian). Landing et al. (2009) reported that faunal remains retrieved from the overlying non-marine facies of the Potsdam in northern New York have yielded a Crepicephalus Zone fauna (Series 3). Hagadorn \& Belt (2008) also reported the presence of a trilobite fauna indicating an uppermost middle Cambrian (Series 3) as present in the middle and upper horizons of the Keeseville and Ausable Formations. This data provides a minimum age for the uppermost Altona Formation.

Biostratigraphic studies of fauna contained in the Cambrian strata in northern New York-southern Quebec Basin (Landing et al. 2009 and references therein) and western Vermont (Palmer \& James 1979, Mehrtens \& 
Gregory 1984 and references therein; Fig. 2) indicate that the age of post-rift, marine shelf deposits in Vermont are significantly older than those in the northern New York-southern Quebec Basin, reflecting the westward transgression of the Iapetus seas onto Laurentia. Thus, the initial Sauk transgression (Sloss 1963) onto the Laurentian Craton occurred earlier in Vermont, younging westward into northern New York.

\section{Study area and methodology}

The study area is in northeastern New York State, approximately $15 \mathrm{~km}$ northwest of Plattsburgh (Fig. 3) in Clinton County. Outcrops of the Altona Formation are limited in number beneath the more well-exposed overlying units of the Potsdam Group. In assembling the composite stratigraphic column of the Altona Formation (Fig. 4) this study focused on five outcrops and one well log drill core which determined that the Altona in this region is approximately 84 meters thick. As documented by Lowe et al. (2017) the Altona thins to the north into the Quebec Basin to approximately 36 meters in thickness.

Outcrops were measured and described at the centimeter scale with particular attention to sedimentary structures, which include cross lamination, hummocky cross stratification, oscillatory ripples, graded bedding, trough and planar cross stratification, herringbone cross stratification, horizontal laminations, and bioturbation. Although not numerous when available, measurements were taken of cross bedding to provide data on paleoflow direction. Covered intervals were measured by surveying. In addition to outcrop data, chips from one well drilled through the Altona (drill chips provided to the authors from David Franzi, S.U.N.Y. Plattsburgh) were also examined. Gamma-ray log data from the same well and details

Figure 2. Correlation chart for Cambrian to Lower Ordovician strata in western Vermont and northwestern New York. Abbreviations: $\mathrm{Pc}-$ Parker conglomerate; RB - Rugg Brook conglomerate; RL - Rockledge conglomerate. Radiometric ages on the Cambrian-Ordovician boundary from Landing et al. (2000) and the PrecambrianCambrian boundary from Gradstein et al. (2004).

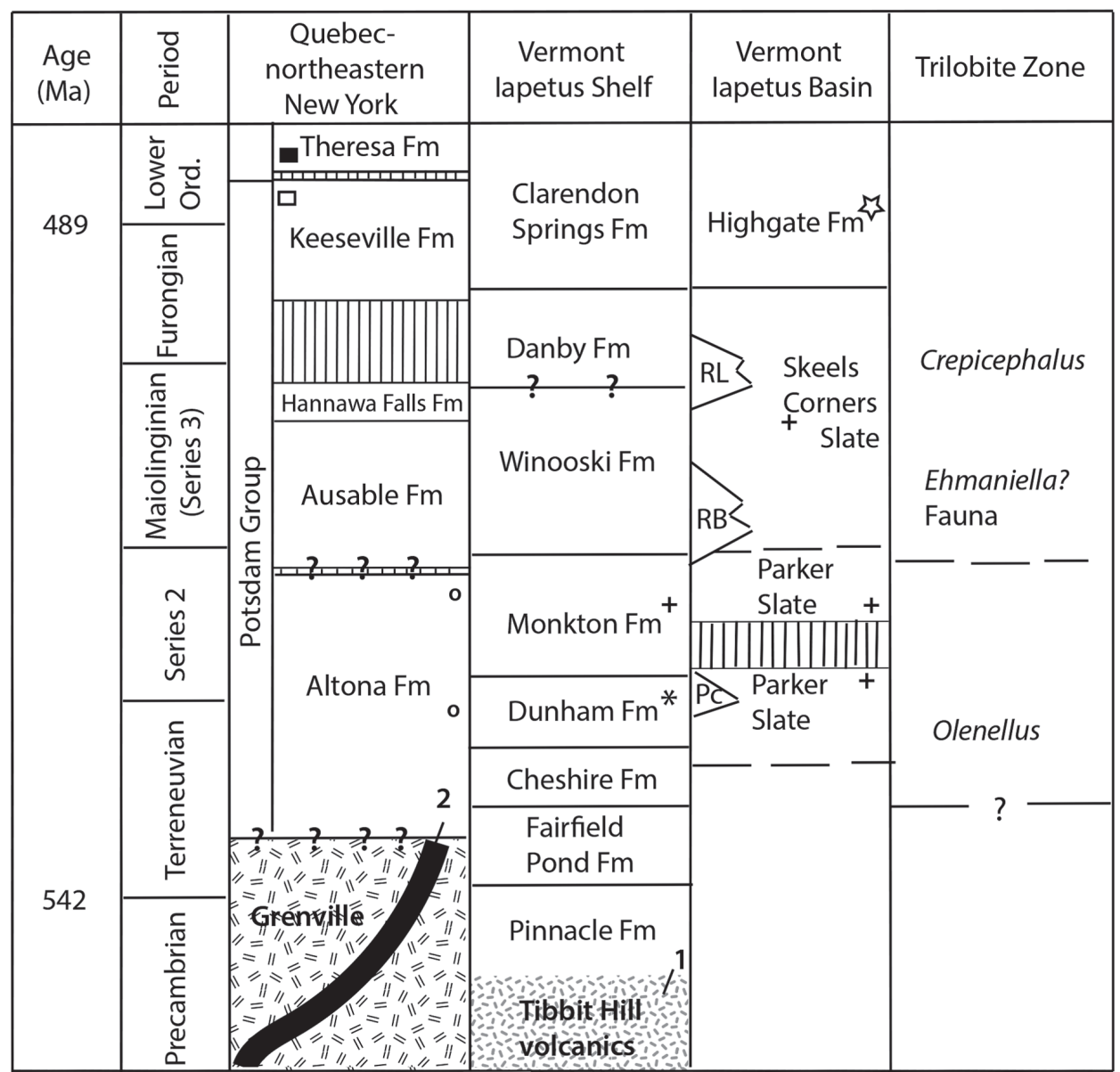

Key: $\mathrm{RL}=$ Rockledge Cong; $\mathrm{RB}=$ Rugg Brook Cong; $1=$ radiometric age from Malka et al. (2000); 2 = radiometric age from Kumarapeli et al. (1989); o = Landing et al. (2009);

* = Mehrtens \& Gregory 1981); + = Palmer \& James (1979 and references therein); $\boldsymbol{\xi}=$ Landing (2007); $\square=$ Nowlan (2013); $\boldsymbol{\square}=$ Brand \& Rust (1977); vertical lines represent unconformities 


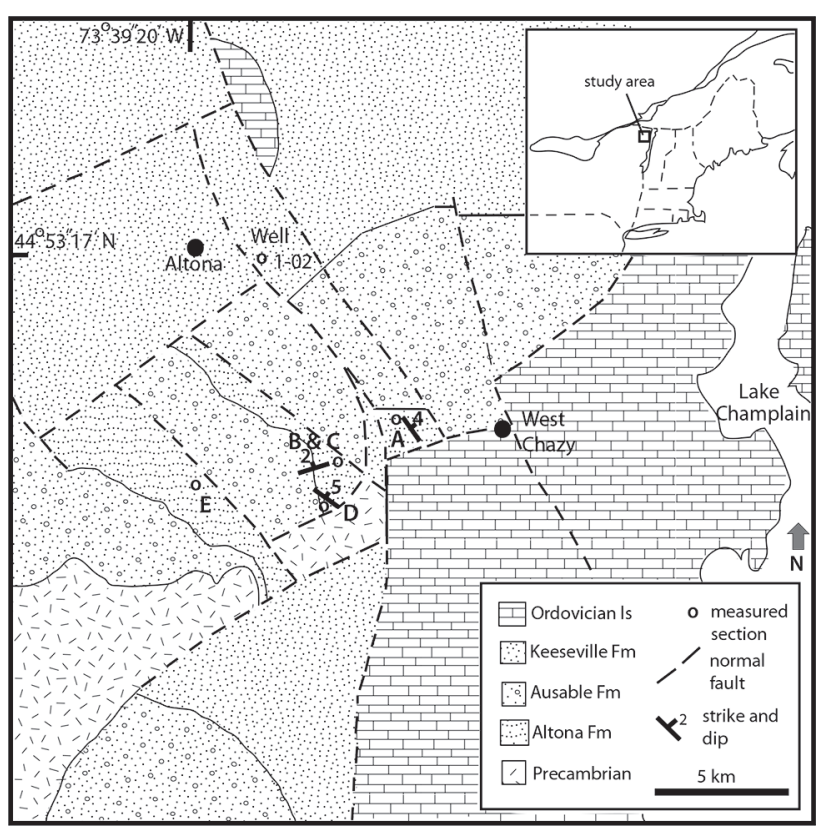

Figure 3. Geologic map of the study area, including unpublished data provided to the senior author by David Lowe. See also Lowe et al. (2015). Locality A - Atwood Farm (UTM Zone 18: 0613737 E, 4964653 N); B and C - McKinney Farm (UTM Zone 18, 0611758 E, 4962606 N); D - lower Murtaugh Hill stream (UTM Zone 18: 0611739 E, 4961998 N); E - top of Murtaugh Hill (UTM Zone 18: 0610762 E, 4960784 N). The location of well 1-02 at is shown (UTM Zone 18: 0612713 E, 4965740 N).

of the well log and cycle interpretation were collected by Edwin Romanowicz (S.U.N.Y. Plattsburgh) and are reported in Maguire et al. (2018). Samples were collected throughout all sections for hand sample and petrographic examination.

Uranium-lead data from zircons in the Altona were provided by Chiarenzelli et al. (2010) from Altona samples collected near Potsdam, N.Y., to the west of present study's field area. Their results are discussed below.

Compositional data was obtained from thin sections. The fine grain size and hematite staining made it necessary to examine thin sections with a scanning electron microscopy with EDS and cathode luminescence. Thin sections from each of the lithofacies were examined. Multiple transects across thin sections confirmed grain size measurements made from transmitted light microscopy and provided the basis for grain identification and point count data. The composition of mudstones was determined by Xray diffraction.

\section{Results}

\section{Construction of the composite section}

While we acknowledge that it is possible that irregular Precambrian topography could produce thickness dif- ferences in the Altona Formation, the composite section presented here is based on the total unit thickness of 84 meters between basement and the overlying Ausable Formation retrieved from well 1-02. A composite stratigraphic section was constructed from three of the five outcrops (Atwood Farm: Fig. 5, McKinney Farm: Fig. 6, and lower Murtaugh Hill: Fig. 6). Neither the base nor top of the Altona was exposed at the Purdy Mills outcrop (Fig. 6), so its position in the composite section cannot be placed with any certainty. The exposure at the top of Murtaugh Hill, although close to exposures of overlying younger Potsdam strata, likewise cannot be placed accurately in the stratigraphy but lithologies and sedimentary structures suggest that it is near the top of the Altona. The lower Murtaugh Hill stream channel exposure off Route 190 contained the contact of the Altona with basement. The Atwood Farm exposure did not extend down to basement but reached the upper contact with the overlying Ausable Formation. The McKinney Farm section overlapped a portion of the Atwood Farm section.

\section{Depositional Facies}

Hampson (2000, tab. 1) described four subdivisions of shelf to shoreface environments. This include: (1) offshore shelf/ramp, (2) distal lower shoreface and inner shelf/ramp, (3) proximal lower shoreface and (4) upper shoreface. Hampson's (2000) upper shoreface includes sediments deposited above fair-weather wave base; his lower shoreface environments represent deposition above storm wave base but below fair-weather wave base and the offshore shelf environment represents sediment deposited below storm wave base. As noted by Rey \& Hidalgo (2004), along shorelines where tidal processes are a factor, a fifth setting, the subtidal to intertidal environment of the foreshore/shoreface, is also important to identify.

The key attributes of grain size, sedimentary structures, sorting, bed thickness, bedding contacts and discontinuity surfaces used to distinguish wave-dominated environments are well described (Elliot 1986 and references therein, Walker \& Plint 1992 and references therein, Pattison 1995) and are not repeated here. These attributes form the basis for the identification of six lithofacies in the Altona Formation (Tab. 1 and Figs 7-12). A depositional model for the distribution of lithofacies is shown in Fig. 13.

\section{Lithofacies 1: non-marine to marginal marine}

Lithofacies 1 (Fig. 7) consists of a medium to coarsegrained poorly-sorted arkosic sandstone. Sandstone beds $10-20 \mathrm{~cm}$ in thickness contain $10-15 \mathrm{~cm}$ thick isolated 


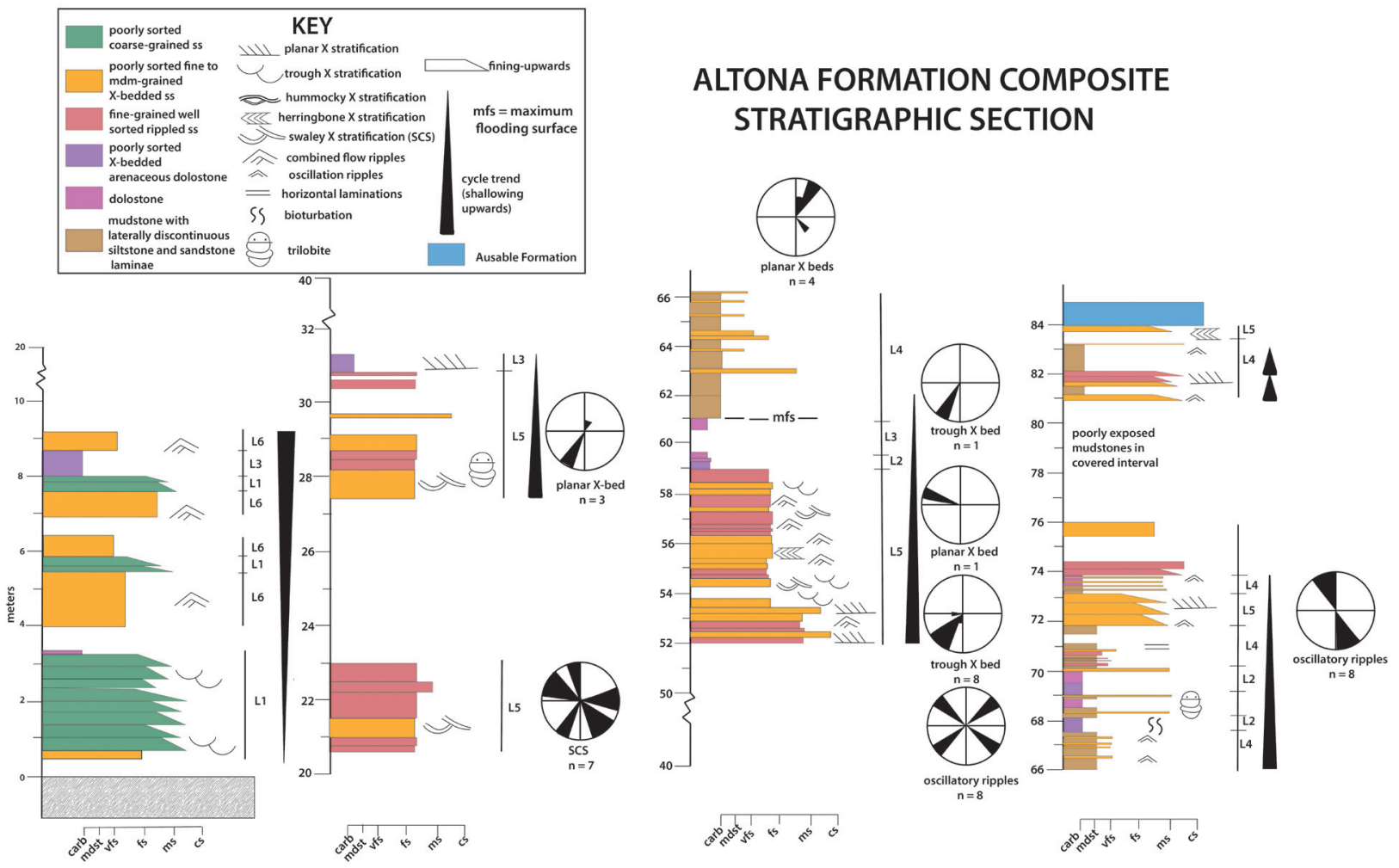

Figure 4. Composite stratigraphic section of the Altona Formation. Scale is in meters. Abbreviations: SCS - swaley cross stratification; carb-carbonate; mdst - mudstone; vfs - very fine-grained sandstone; f - fine-grained sandstone; ms - medium-grained sandstone; cs - coarse-grained sandstone.
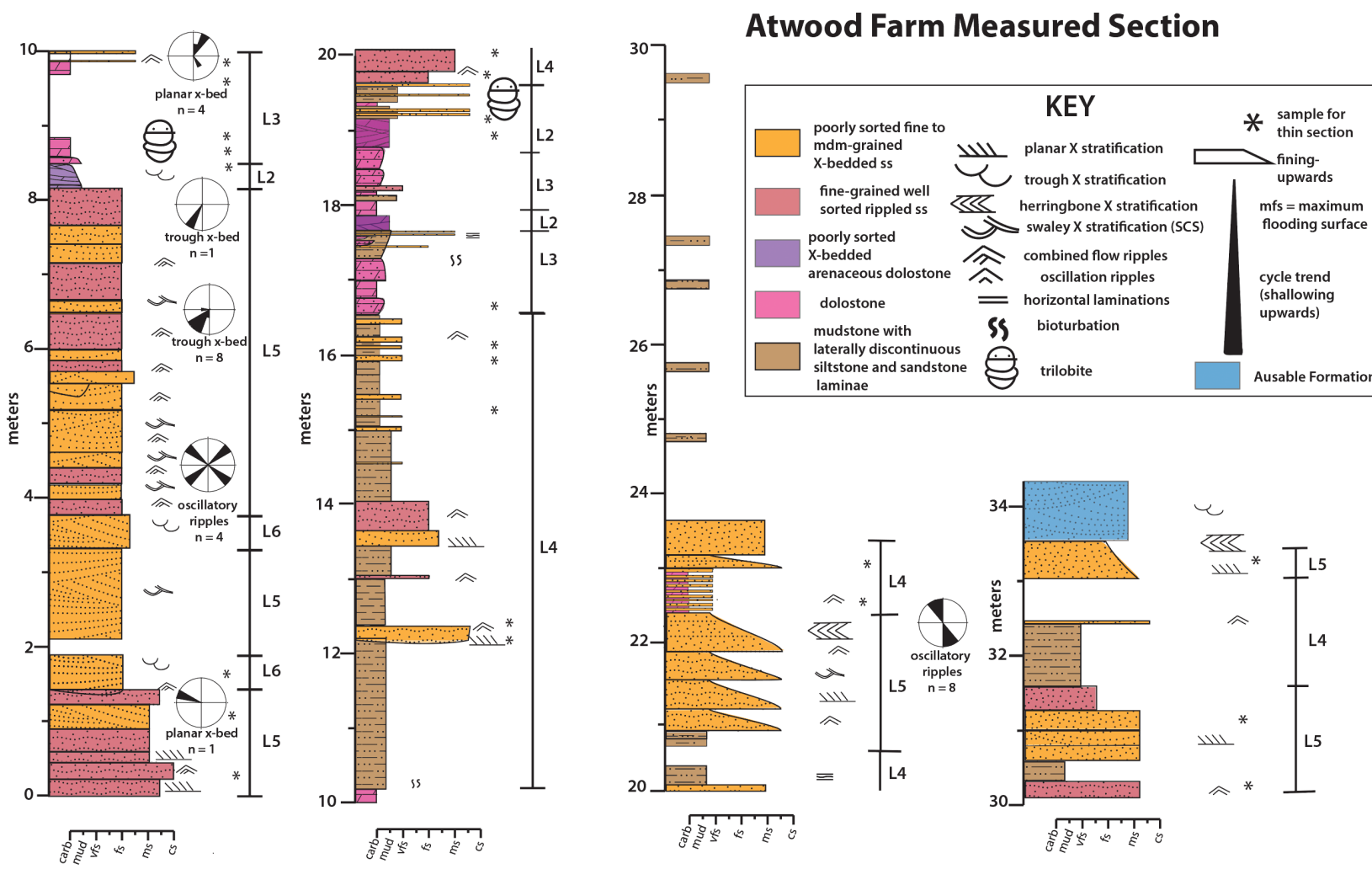

Figure 5. Measured section from Atwood Farm. Vertical scale in meters. Key to symbols for Figs 6-12. 
Table 1. Summary of lithofacies.

\begin{tabular}{|c|c|c|c|}
\hline Lithofacies & Description & Interpretation & Representative stratigraphy \\
\hline 1 & $\begin{array}{l}\text { medium to coarse-grained poorly sorted sandstone with } \\
\text { rare gravel horizons; trough and planar cross stratification }\end{array}$ & $\begin{array}{l}\text { fluvial (sheetflow) to marginal } \\
\text { marine }\end{array}$ & on PC basement \\
\hline 2 & $\begin{array}{l}\text { dolostone and arenaceous dolostone with siltstone. Coarse- } \\
\text { tail graded bedding and cross lamination, bioturbation }\end{array}$ & nearshore carbonate pond & middle of Atwood Farm \\
\hline 3 & $\begin{array}{l}\text { arenaceous dolostone containing poorly sorted medium- } \\
\text { grained sand exhibiting graded bedding and cross } \\
\text { lamination }\end{array}$ & $\begin{array}{l}\text { nearshore shelf adjacent to } \\
\text { terrigenous source with periodic } \\
\text { 2D and 3D bedload deposition }\end{array}$ & base of Atwood Farm. \\
\hline 4 & $\begin{array}{l}\text { heterolithic: red and grey mudstone with thin laterally } \\
\text { discontinuous beds of sand, silt and dolostone; ss beds } \\
\text { are cross laminated with planar bases; bioturbation }\end{array}$ & $\begin{array}{l}\text { nearshore estuarine/bay quiet } \\
\text { water with periodic tempestite } \\
\text { deposition }\end{array}$ & Atwood Farm, Purdys Mills \\
\hline 5 & $\begin{array}{l}\text { poorly sorted medium-grained feldspathic ss, trough, } \\
\text { planar, swaley and hummocky cross stratification,graded } \\
\text { bedding and cross lamination }\end{array}$ & $\begin{array}{l}2 \mathrm{D} \text { and } 3 \mathrm{D} \text { dunes nearshore } \\
\text { wave reworked fairweather } \\
\text { and tempestite deposits }\end{array}$ & $\begin{array}{l}\text { lower third and top of Atwood } \\
\text { Farm }\end{array}$ \\
\hline 6 & $\begin{array}{l}\text { fine to medium-grained well sorted ss. Upward-bundling } \\
\text { ripples, combined flow ripples, erosional surfaces are } \\
\text { common }\end{array}$ & $\begin{array}{l}2 \mathrm{D} \text { and } 3 \mathrm{D} \text { wave-generated } \\
\text { ripples on storm-influenced } \\
\text { upper-middle shoreface }\end{array}$ & middle of Atwood Farm \\
\hline
\end{tabular}
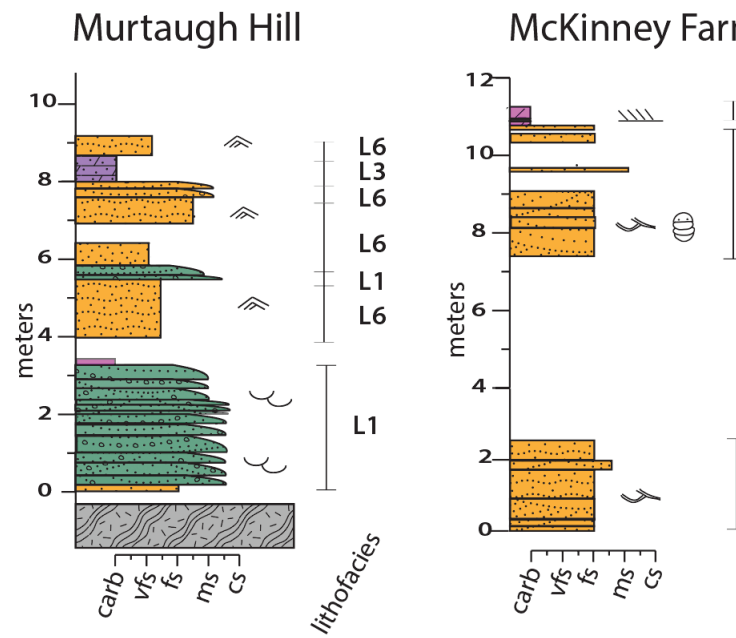

sets of trough cross stratification and stacked sets which may be capped by $2 \mathrm{D}$ and $3 \mathrm{D}$ ripple cross lamination. The bases of beds are very sharp and bed thickness is constant across limited lateral exposure. Coarse-tail grading is present. This lithofacies lies at the base of the Altona, above Precambrian basement at the lower Murtaugh Hill exposure.

Sedimentary structures present in this lithofacies are not unique to any depositional environment; however the coarse grain size and poor sorting suggest rapid deposition from sediment-laden high velocity flows. Single sets of cross beds present in this lithofacies represent sediment deposited as bedload as sinuous-crested migrating

\section{Purdys Mills}

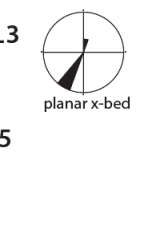

Figure 6. Measured sections from Murtaugh Hill, McKinney's Farm and Purdys Mills. Vertical scale is in meters. Rose diagrams represent paleoflow data from swaley (SCS) and planar cross stratification. Key to symbols as shown in Fig. 5. bedforms (3D ripples of Harms et al. 1982) and stacked sets record the migration of three dimensional ripple fields.

Taken together, the stratigraphic position of this lithofacies immediately above Precambrian basement suggests that it records deposition in a fluvial to marginal marine setting, possibly from sheetflood deposition which may have subsequently experienced reworking by currents. Sand-dominated sheetflood deposits have been described by many authors (e.g., McKee et al. 1967, Bull 1972, Collinson 1978, Tunbridge 1981). They are interpreted as laterally extensive sand bodies which frequently form on the distal reaches of alluvial 
Figure 7. Lithofacies $1 . \cdot \mathrm{A}-$ measured section from lower Murtaugh Hill. The covered interval above the Precambrian basement is approximately $0.3 \mathrm{~m}$ thick succeeded by several meters of cross bedded sandstone. $\cdot$ B outcrop photograph from above the Precambrian contact on lower Murtaugh Hill. $-\mathrm{C}$ - thin section photomicrograph of sample AF 13-20 illustrating the poorly sorted texture of a sandstone. D - bipolar flow directions produced from cosets of planar cross stratified sandstone. Pencil for scale. - E - arrows point to a pebble horizon at the top of a poorly sorted, cross stratified coarse-grained sandstone. The black scale bar is $2 \mathrm{~cm}$.

Figure 8. Lithofacies 2 is a dolostone to arenaceous dolostone in composition containing poorly sorted medium grained sand, cross stratification and ripple cross laminations. - A - an interval of the Atwood Farm stratigraphy where this lithofacies is exposed in contact with Lithofacies 4 . $\mathrm{B}$ - dolostone bed at Atwood Farm that grades upwards into red silty mudstone. Hammer for scale. • $\mathrm{C}$ - thin section photomicrograph of siltstone. - D stadial rod in front of an outcrop of interbedded dolostone and mudstone at Atwood Farm. - E - color mottling in the fabric of dolostone is interpreted to represent the effects of bioturbation.
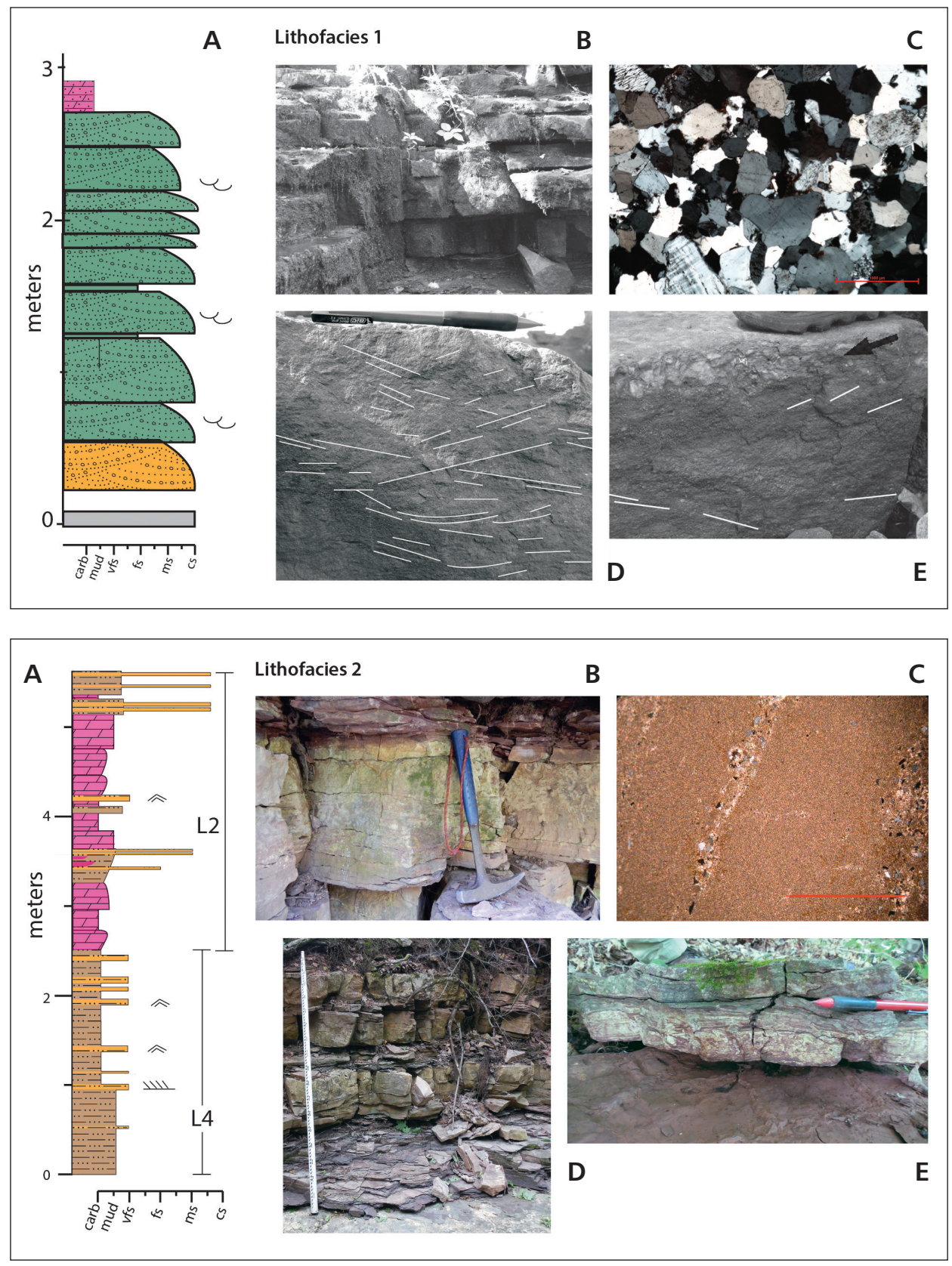

fans. At the lower Murtaugh Hill exposure, 2.5 meters of this lithofacies is overlain by Lithofacies 3 - dolomitic sandstone.

\section{Lithofacies 2: nearshore carbonate}

Lithofacies 2 is a heterolithic unit containing dolostone, siltstone, and fine-grained sandstone exhibiting cyclic transitions between lithologies. Figure 8 illustrates the variety of lithologies and cyclic nature of interbedding of lithologies. Dolostone beds range in thickness from $1 \mathrm{~cm}$ up to $0.5 \mathrm{~m}$ thick and are occasionally silty with some evidence of graded bedding and cross bedding. Thin beds containing terrigenous sediment may exhibit ripple cross lamination. Some beds appear bioturbated. Dolostone beds have no apparent stromatolites, mudcracks, rip up clasts, or other shallow water features, however Lowe (personal communication, 2015) reported finding cryptalgal structures in thin section. This lithofacies is located in the middle of the Atwood Farm section and is associated with Lithofacies 4 . This lithofacies yielded specimens of Ehmaniella trilobites (Landing et al. 2009).

The carbonate sediment of Lithofacies 2 is interpreted to be the result of biomineralization from calcareous algae. This lithofacies is interpreted to record clear water bio- 
genic carbonate deposition in a setting on the shelf adjacent to fine-grained terrigenous material. The fine grain size of terrigenous sediment implies a relatively low energy setting. The mottled fabric of silty dolostones (Fig. 8E) is interpreted to be the result of homogenization of dolostone-siltstone couplets through bioturbation.

\section{Lithofacies 3: upper to middle shoreface}

This lithofacies (Fig. 9) consists of dolostone, poorlysorted, medium-grained dolomitic sandstone, and arenaceous dolostone exhibiting coarse-tail graded bedding. More arenaceous beds contain either decimeter scale sets of trough cross stratification or stacked centimeterscale sets of unidirectional and oscillatory rippled cross lamination. Dolostones are interbedded with thin $(<3 \mathrm{~cm})$ siltstone and sandstone beds which can be cross laminated.

As with Lithofacies 2, the carbonate sediment of this lithofacies is interpreted to be algal in origin and it is interpreted to record clear water biogenic carbonate deposited on the shelf when terrigenous sediment supply was limited and possibly introduced by eolian processes. The derivation of siliciclastic material and its segregation into "event beds" is characteristic of a punctuated carbonate/siliciclastic mixing model (Mount 1984).

Graded bedding of any terrigenous sediment is thought to reflect resuspension and settling of sediment from the decelerating current flow. Sets of 3D cross strata are interpreted to represent migrating dune deposits from either/both shoreface currents or post-storm relaxation flows. Sets of cross laminae from both unidirectional and oscillatory flow suggest the close temporal association of both unidirectional bottom currents (longshore or rip) and wave processes.

\section{Lithofacies 4: nearshore bay/estuary}

Lithofacies 4 consists of interbedded mudstone with lesser amounts of sandstone, siltstone, and dolostone in heterolithic bedding (Fig. 10). Mudstone beds are red
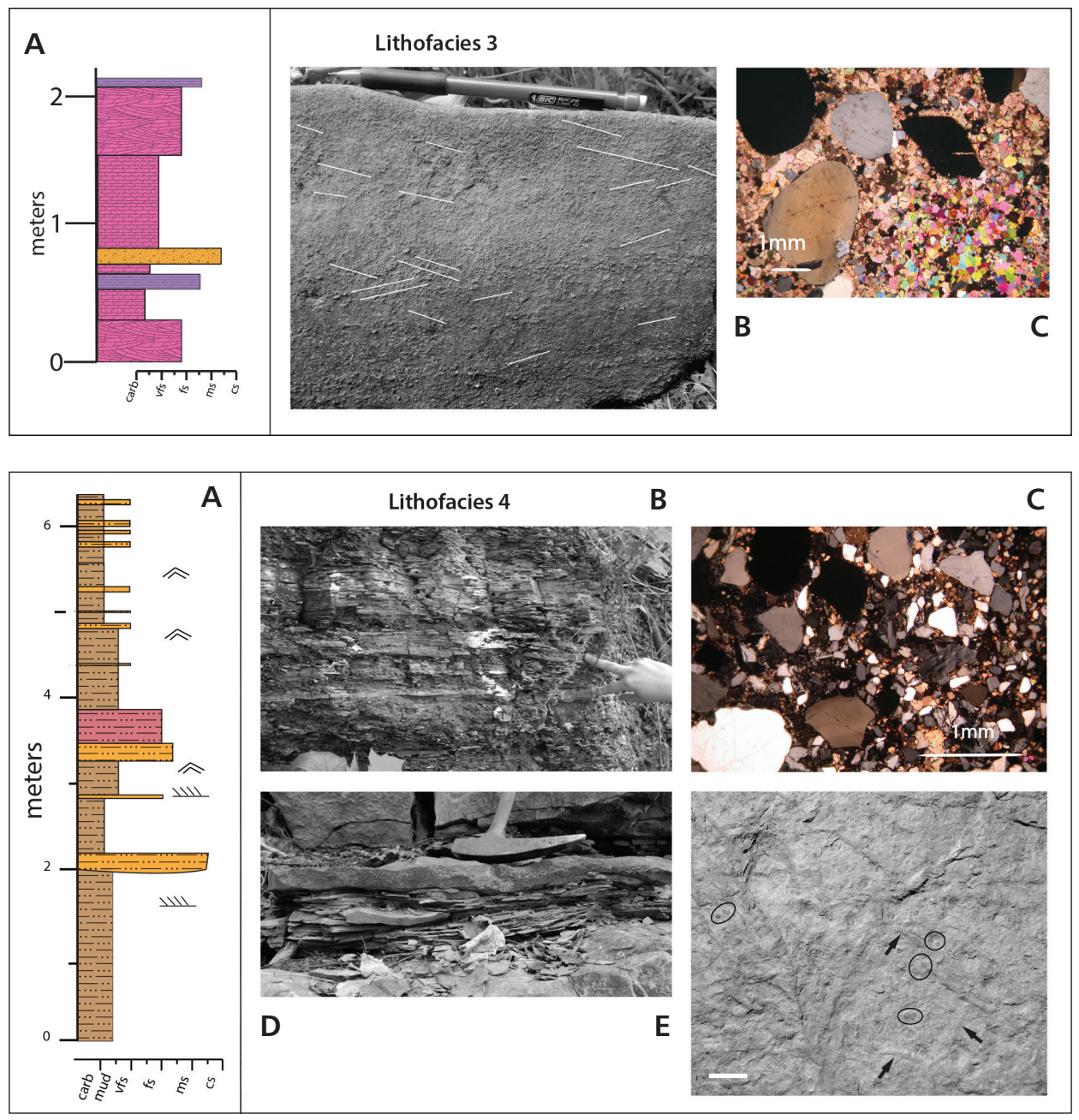

Figure 9. Lithofacies 3. A stratigraphic column of L3 from Atwood Farm. • B - field photo of L3 illustrating graded bedding. Thin black lines accentuate inclined foresets of planar cross stratification. Pencil for scale. $\mathrm{C}$ - photomicrograph of L3 showing poorly sorted medium, well rounded sand in an arenaceous dolostone.

Figure 10. Lithofacies $4 . \cdot \mathrm{A}-$ stratigraphic column from Atwood Farm showing the interbedded nature and bed thickness of the mudstone and sandstone. $-\mathrm{B}$ field photo showing mudstone with thin sandstone and dolostone beds that pinch out laterally. $\bullet \mathrm{C}-$ photomicrograph of a sandstone under cross-polarized light showing the poorly sorted fine sand grain size. $\cdot \mathrm{D}$ - outcrop photo of rippled sandstone in the mudstone at Atwood Farm. Hammer head for scale - E - photograph of Skolithos (circled) and Planolites (arrow) burrows on a bedding plane from Purdy's Mills. White bar is $1 \mathrm{~cm}$ for scale. 


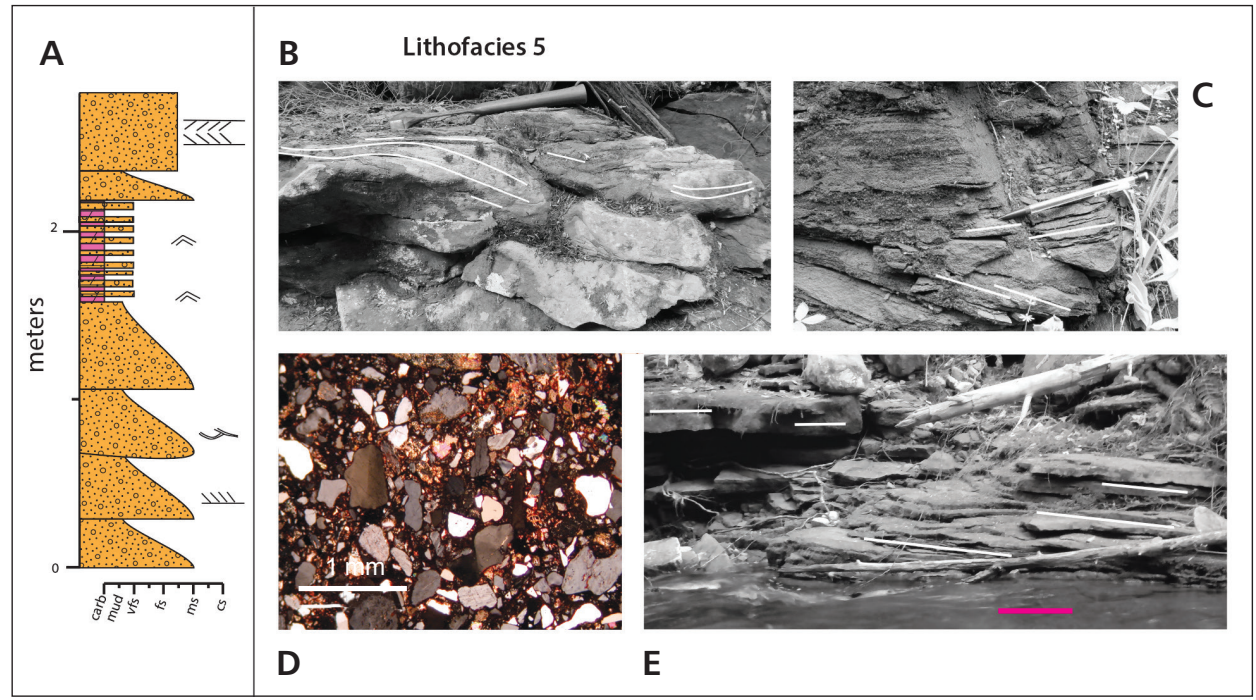

Figure 11. Lithofacies 5. A - stratigraphic column of L5 in association with dolostones of L2 interbedded with sandstones from Atwood Farm locality. $\bullet \mathrm{B}$ - outcrop photograph of swaley cross stratification. Hammer for scale. $\bullet \mathrm{C}$ - herringbone cross stratification is not common in the Altona but this example can be seen at the top of Murtaugh Hill. Pencil for scale. $\bullet$ D - thin section photomicrograph of L5 sands under crossed polarized light. Sands are fine to medium grained and are poorly sorted. The highly birefringent grains are dolomite cement. $\bullet$ E - outcrop photograph of low angle planar stratification from the Atwood Farm locality. Thin white lines accentuate dip direction and magnitude of foresets and the black bar in the upper right is $12 \mathrm{~cm}$ in length.

and gray in color with mm-scale laminations. Very finegrained sandstone beds contain $1 \mathrm{~cm}$ thick (average) ripple cross lamination. The bases of these beds are characteristically planar and beds are laterally continuous across many meters of outcrop. Other sandstone beds have wavy tops and bases and are more laterally discontinuous. Isolated lenses of sandstone $5-10 \mathrm{~cm}$ in length and $103 \mathrm{~cm}$ in height occur within the mudstone. The internal structure of these lenses indicates that they consist of uniformly inclined cross laminations. Buff-colored dolostone beds also occur in the mudstone as $1-2 \mathrm{~cm}$ thick lenses or laterally discontinuous beds. Landing et al. (2009) report occurrences of small Cruziana and Rusophycus trace fossils from this lithology at Atwood Farm and traces of Skolithos, and Planolites were identified at the Purdys Mills locality.

Lithofacies 4 is interpreted to record deposition of nearshore mud in a low energy setting, possibly a bay, lagoon or estuary. Deposition of the mudstone could represent lower energy suspended sediment deposition or it could also record deposition from high mud concentrations associated with a discharge event (McCave 1984, Wilson \& Schieber 2014). The presence of bioturbation suggests lower sedimentation rates. Interbedded rippled sandstone beds are interpreted to be tempestites and the heterolithic bedding suggests that these were frequent. The deposition of carbonate sediment would require periodic "clear water" conditions, perhaps reflecting the presence of an adjacent shallow marine carbonate environment. The interbedding of clastic and carbonate lithologies in this lithofacies may reflect the "facies mixing" process of Mount (1984). Landing et al. (2009) interpreted the red coloration of mudstones to reflect oxygenation of the water column, a phenomenon which these authors interpreted to reflect a shallow depositional setting.

\section{Lithofacies 5: middle to upper shoreface}

This lithofacies (Fig. 11) is a poorly sorted, feldspathic, fine to medium-grained sandstone with variable amounts of dolomite cement containing a variety of sedimentary structures, including planar, trough, hummocky (HCS), swaley (SCS), and herringbone cross stratification. Sets of planar and trough cross stratification range between 15 and $20 \mathrm{~cm}$ in thickness. HCS sets are most commonly $\sim 10 \mathrm{~cm}$ in thickness with wavelengths of $<1 \mathrm{~m}$ however a $70 \mathrm{~cm}$ thick set with a wavelength of $\sim 10 \mathrm{~m}$ is present at the Purdys Mills locality overlying a swale $20 \mathrm{~cm}$ deep and one meter wide. Sandstone beds commonly have planar or erosional bases and are laterally discontinuous, pinching out over 10 meters. Horizons exhibiting cross bedding are frequently topped by $2 \mathrm{D}$ or 3D weakly asymmetrical ripple cross laminae in sets $1-3 \mathrm{~cm}$ in height. Sandstone beds may exhibit coarse-tail grading.

Based on this suite of sedimentary structures, which record both oscillatory and combined flow processes at a range of scales, Lithofacies 5 is interpreted to represent sediment that accumulated on a wave-dominated shoreface that was periodically inundated by storms. Sets of planar cross stratified sandstone are interpreted to represent 
large migrating bars under primarily unidirectional flows under normal fair-weather conditions. Such features are common on the shoreface as a result of longshore and onshore currents (Clifton et al. 1979). Sets of 3D cross strata are interpreted to represent migrating dune deposits from either/both rip currents or post-storm relaxation flows. Sets of cross laminae from both unidirectional and oscillatory flow suggest the close temporal association of both unidirectional bottom currents (longshore or rip) and wave processes. The presence of HCS suggests deposition from high energy conditions of either pure oscillatory flow or oscillatory-dominated combined flow conditions (Dott \& Bourgeois 1982, Harms et al. 1982, Arnott \& Southard 1990, Dumas et al. 2005). Swaley cross stratification is a bedform that is more indicative of storm and post-storm conditions (Lecki \& Walker 1982), which pass vertically into either ripple cross lamination sets or 3D trough cross beds with erosional bases; such features are interpreted to record deposition from either/both rip currents or poststorm relaxation flows on the upper or middle shoreface waning flow following storm conditions (Dumas et al. 2005). Flows of this type have been identified by Swift et al. (1986) on the Atlantic shelf following storms, where cyclonic flow drives water landward, followed by pressure gradients that drive a bottom return (downshelf) flow. Paleoflow data from this lithofacies (Figs 4, 5) range from SW to NW and such variation can be the result of variation in storm wave energy and variability in wave approach and bottom flow currents.

As noted by Dumas et al. (2005), combined flow conditions can be found over a broad range of environments and thus its presence is more indicative of flow conditions than environmental setting. Likewise, 2D and 3D upward bundling ripples are interpreted to represent aggrading bedforms that form in oscillatory flows, a minor unidirectional flow component, and a consistent sediment supply (de Raff et al.1977, Harms et al. 1982). Graded bedding is interpreted to reflect resuspension and settling of sediment from the decelerating flow of currents.

\section{Lithofacies 6: middle to upper shoreface}

Lithofacies 6 (Fig. 12), the most common lithology in the Altona Formation, is a very fine to medium-grained moderately well-sorted sandstone with variable amounts of dolomite cement. Cross laminations, both form concordant and form discordant, are characteristic of this lithofacies. Individual sets range from less than $1 \mathrm{~cm}$ in height to $3 \mathrm{~cm}$ with wavelengths up to $10 \mathrm{~cm}$. As seen in Fig. 12B, the internal structure of a ripple with a symmetrical profile often contains $\mathrm{mm}$-scale laminations produced from unidirectional flow, a feature that is characteristic of "combined flow" of unidirectional and oscillatory motion. Also common are stacked bidirectional ripple cross laminations ("upward bundling ripples" of de Raff et al. 1977). The thickness of beds containing rippled fine-grained sandstone can be up to $50 \mathrm{~cm}$ in thickness but this can change laterally (thins) over tens of meters of outcrop. This lithofacies is associated with the cross bedded sandstones of Lithofacies 5 (Fig. 11).

The combination of fine to medium-sand grain size, moderate to good sorting and abundant cross laminations indicates that this lithofacies records bedload deposition on the middle to upper shoreface from migrating $2 \mathrm{D}$ and $3 \mathrm{D}$ ripples which are often subsequently be reworked by oscillatory wave motion.

\section{Facies Model}

Construction of a facies model for the Altona Formation takes into account several features: (1) the stratigraphic occurrence of the unit above Precambrian basement; (2) an abundance of wave-generated sedimentary structures; (3) mixed siliciclastic and carbonate lithologies; (4) the presence of marine ichnofacies and trilobite fragments; and (5) sedimentary structures that record storm-influenced sedimentation. The absence of evidence of subaerial exposure, such as mudcracks, and the relative paucity of tidally-influenced structures such as herringbone cross stratification. While paleocurrent data (Figs 4,5) indicates bipolar and multi-directional flow often associated with tidal processes (Yang et al. 2005 and references therein), these flow directions would also be expected from fairweather and post-storm flow conditions. For these reasons a tidal-flat interpretation for the Altona Formation is rejected.

Based on grain sizes, sedimentary structures and stratigraphic occurrence the six lithofacies of the Altona Formation are interpreted to have formed on a marine shelf (Fig. 13). Except for the basal horizons (L1), interpreted to be sheetflood deposits of sediment shed off Precambrian basement, the remaining lithofacies were deposited on the nearshore, shoreface, and offshore portions of a shelf that experienced episodic discharge from sheetflow or ephemeral streams and deposition from wind-blown sand. The dominance of episodic "flashy" discharge onto the shelf is also supported by climate models for the early Cambrian (Boucot et al. 2013) which indicate that the Laurentian margin lay within the sub-equatorial arid belt. Arid conditions would inhibit creation and maintenance of stable fluvial systems that could provide more continuous clastic input to the shelf. The preponderance of sedimentary structures indicates that clastic sediment was reworked by wave and current processes. The sedimentary structures present in dolostone horizons suggests that some carbonate sediment 
Figure 12. Lithofacies 6 . A stratigraphic column showing bed thickness of L6 and their association with beds of L5. $-\mathrm{B}$ field photos of L6 illustration of combined flow ripples above erosional surface. Part of pencil for scale. $\cdot \mathrm{C}-$ photomicrograph a L6 under crossed polarized light. This lithofacies is moderately well sorted and is a very fine to medium-grained sand. $\bullet$ D - field photo of a rippled bedding plane at Atwood Farm. - E - photograph of upward bundling cross lamination at McKinney Farm. The black bar in the lower right is $10 \mathrm{~cm}$ in length.

Figure 13. Cartoon illustrating proposed depositional environments for Altona Formation lithofacies. Stream and sheetflow drainage off the Adirondack source area, combined with wind-transported sediment, is deposited in a series of shoreface settings. Laterally adjacent to sheetflood deposits fine-grained clastic and carbonate sediment could accumulate. Further offshore waves rework sediment producing a variety of ripples, dunes and bars.
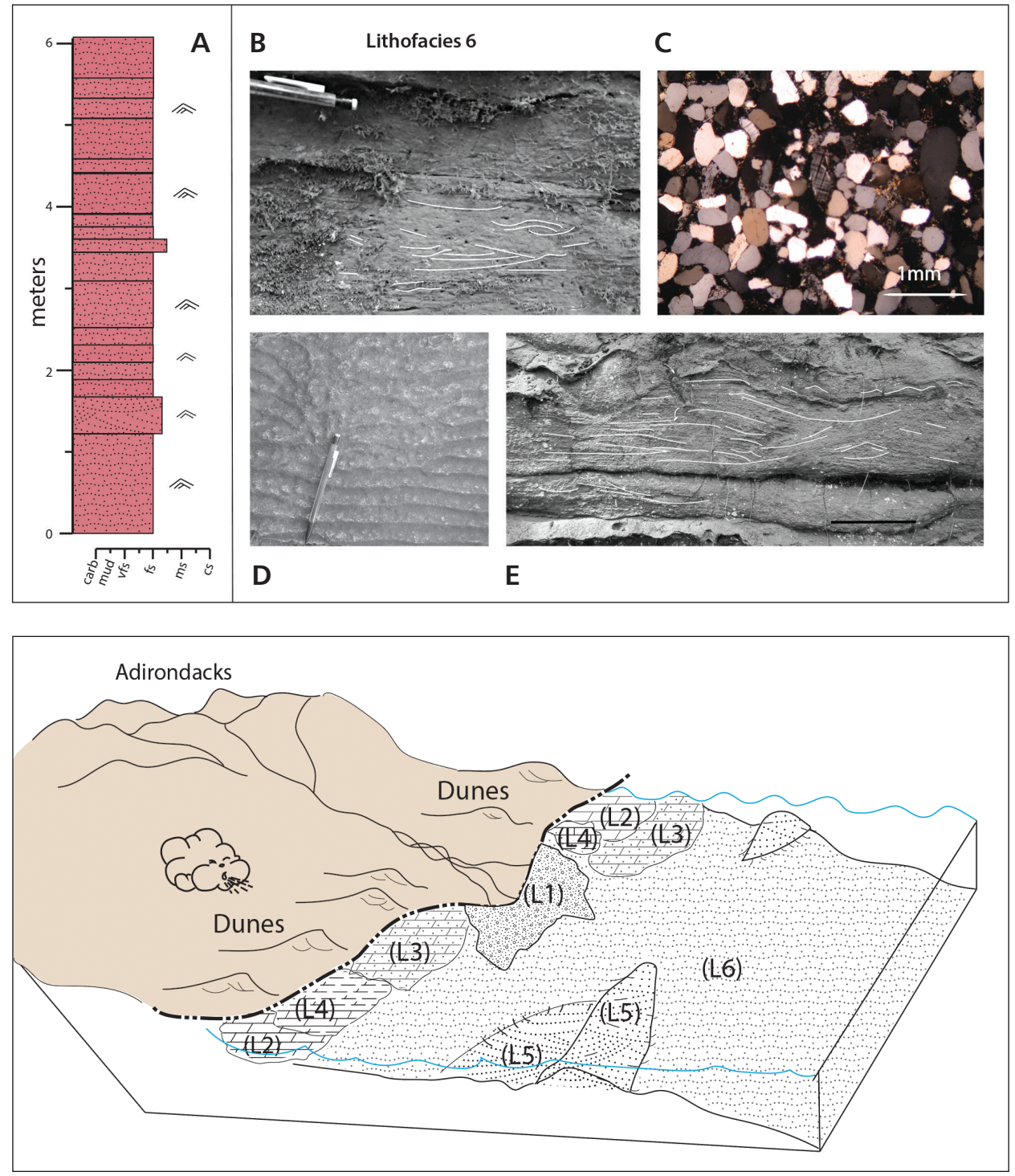

did accumulate in a nearshore setting, which implies that it was spatially segregated from siliciclastic input. Mixing of carbonate and clastic sediment occurred via the punctuated and facies mixing models of Mount (1984). There are several modern analogues for the proposed shoreline model, including Puerto Rico (Pilkey et al. 1988), where carbonate sediment accumulates spatially removed from a terrigenous point source and clastic and carbonate mixing occurs as a result of storm processes, and the Brazilian shelf, where Testa \& Bosence (1998) described a mixed deposition on a coastal ramp where a combination of clastic sediment supply, fluctuating sea level and ocean hydrodynamics spatially segregate sediment types. Because the distribution of facies on modern shelves reflects the interplay between sediment supply and dynamic Quaternary glacio-eustatic sea level changes, like the modern example described by Testa \& Bosence (ibid), we would expect the spatial distribution of environments to change over time as both sediment and sea level reach equilibrium.

\section{Cyclicity and vertical successions}

\section{Outcrop}

The abundance of covered intervals in the Altona outcrops makes the identification of cyclicity in outcrops difficult but one common occurrence is shown in Fig. 14. Here, cross stratified fine to medium-grained sandstones of Lithofacies 5 (white bar 1) are overlain by fine to very fine-grained cross laminated sandstones of Lithofacies 6 (white bar 2) which are overlain by an erosional surface (base of white bar 3) overlain by another cross stratified unit (Lithofacies 5). Based on the environmental interpretations presented earlier, these cycles are 


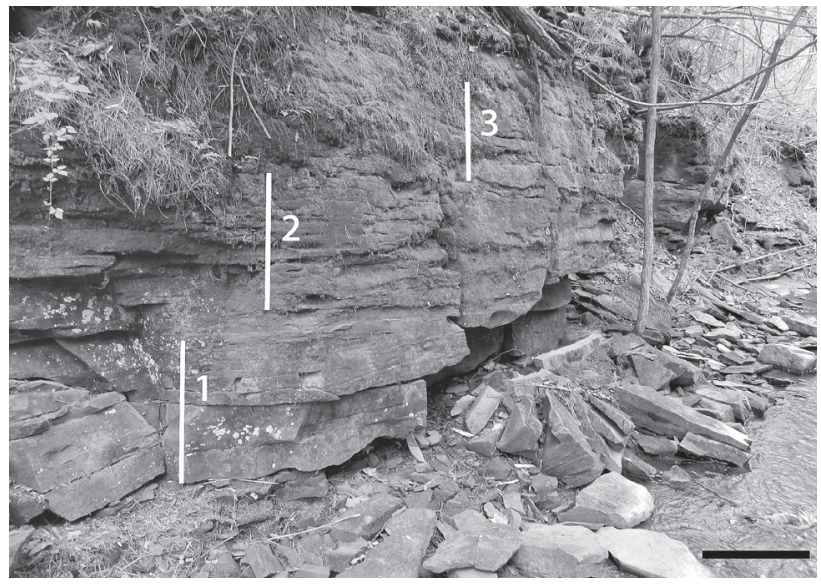

Figure 14. Cycles in the Altona. Numbers 1, 2 and 3 bracket parts of a cycle; 1 is Lithofacies 5 succeeded up (2) section by Lithofacies 6 . There is an erosional contact with interval 3 , Lithofacies 5 . The black bar is $50 \mathrm{~cm}$ for scale.

interpreted to be autocyclic in origin, reflecting storm generated inner shelf sand bar migration followed by fairweather wave reworked shoreface sands.

\section{Gamma Ray Log Analysis}

Farrell et al. (2013) presents gamma-ray log response patterns from four shelves to shoreface stratigraphies of Cretaceous to Holocene age. They demonstrated that gamma-ray data can complement facies analysis, descriptive field data and sea level history, making it possible to identify characteristic gamma-ray signatures for portions of a shelf to shoreface shallowing-upwards sequences. Such sequences accompany the transition from transgressive systems tract (TST) to highstand systems tract (HST) conditions (systems tract terminology after Catuneanu 2002, Catuneanu et al. 2009). Bathymetry and associated hydrodynamic conditions across the shelf to shoreface produce variation in grain size, and gammaray emissions are controlled by the concentration of radiogenic elements in compositions (e.g., clay minerals) and grain size [hydraulic sorting of accessory minerals (Trask \& Hand 1985)]. Using these relationships, Farrell et al. (2013, Fig. 14) summarized the characteristic gammaray patterns produced for the upper shoreface, lower shoreface and open shelf environments in a Holocene well $\log$, where sea level history is well known, and used this information to interpret the gamma-ray log patterns in older examples. We use a similar approach in this study.

A condensed, smoothed record of the gamma-ray $\log$ data from a well through the Altona Formation and reaching Precambrian basement was presented in Landing et al. (2009, Fig. 8) and compared to the stratigraphy they described at Atwood Farm. The data they presented clearly identifies the low gamma-ray value horizons in the stratigraphy that they interpreted as characteristic of dolostone and arenaceous dolostone beds. However, at the level of resolution they presented no further trends in the data set were evident. The Atwood Farm exposure also does not reach to the base of the unit. In order to determine if the characteristic gamma-ray patterns of shelf and shoreface environments could be identified in the Altona well, and if statistical analysis could reveal cycles, raw gamma-ray log data for the same Altona well 1-02 was processed at a higher level of resolution. The data was statistically analyzed to determine if patterns were identifiable and if so, whether or not the patterns reveal trends or cycles through the Altona stratigraphy. Maguire et al. (2018) contains the full gamma emission data set as well as a Mortlet wave analysis of this data, with results which indicate that meter-scale cyclicity is present but poorly developed throughout the entirety of the Altona Formation. Longer period cycles (tens of meters) are present in the lower half of the unit. A portion of their analysis is presented in Figs 15, 16.

In Fig. 15 gamma emission data is plotted at a level of resolution that clearly indicates that the well 1-02 stratigraphy can be viewed as consisting of three intervals with distinct maximum and minimum gamma values and cycle periods: 126 to 107 meters below the well top ( 0 to 20 meters above the base of the Altona composite stratigraphic section), 107 meters to 87 meters depth in the well (20 meters in the section to 41 meters in the composite section), and above 41 meters (upper Altona and the base of the Ausable Formation). Of these, the second interval is the most distinctly different from other portions of the Altona stratigraphy.

Figure 16 shows gamma emission data through well 1-02 at a much higher level of resolution plotted against the Altona Formation composite stratigraphic section and biostratigraphic data (from Landing et al. 2009). The three intervals identified in Fig. 15 are also shown as are two possible sequence stratigraphy interpretations of the data (discussed below). Within Interval 1, the basal 4 meters of Altona stratigraphy (red arrow 1) is represented by the gradually increasing gamma values that records the onlap of Precambrian basement during transgression. This is followed up section with the "sawtooth" gamma emission pattern that Farrell et al. (2013) described as characteristic of shoreface successions. Within this "Interval 2" of the stratigraphy, two portions of the data set (red arrows 2 and 3) clearly show examples of cycles produced by the transition from more carbonate-rich sediment with low gamma values (dolostones and arenaceous dolostones) to higher gamma values from carbonate poor (arkosic sandstones), or coarsening-upwards, on the shelf. Cycles between the sand bars (Lithofacies 5) and wave rippled sands (Lithofacies 6) such as those illustrated in Fig. 14 are too small to be seen at this scale. At the top of Interval 2 
Figure 15. Cyclic gamma emission pattern in the Altona and lower Ausable Formations. The data falls into three intervals. See text and Fig. 16 for discussion.

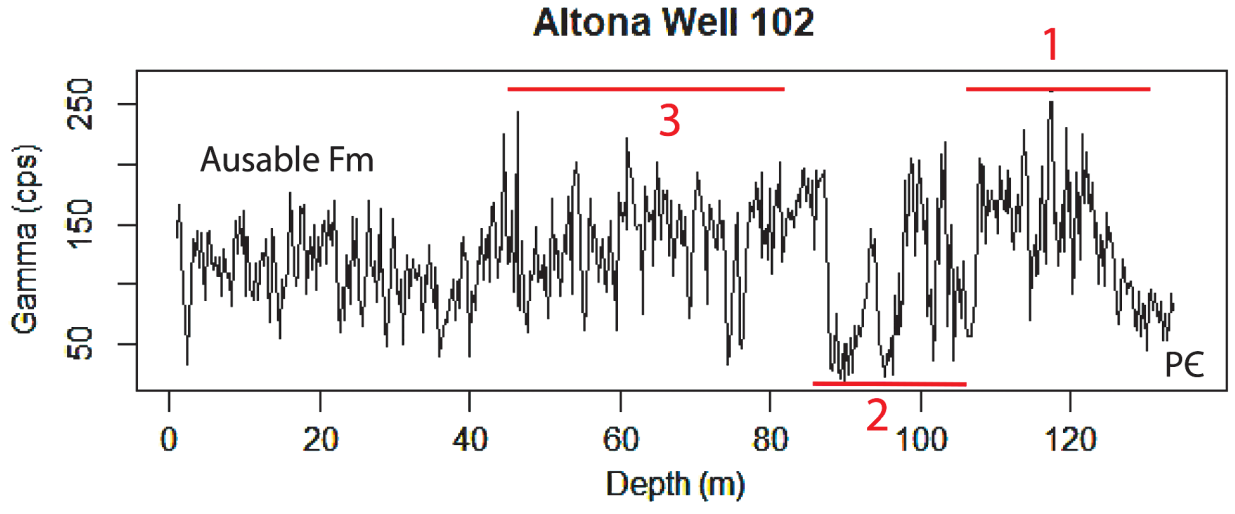

the 11 meter thick section in the well between 97 to 88 meters ( 31 to 42 meters in the composite section) is characterized by low gamma values which we interpret to record the most dolomitic portion of the Altona stratigraphy (Lithofacies 2). In Interval 3, the gradual decrease in gamma values from 46 to 52 meters and above 76 meters (red arrows 4 and 5) is interpreted to record increasing carbonate content in the sandstones. The uppermost cycle (5), representing increasing carbonate cement content, abruptly terminates at the contact with the overlying non-marine Ausable Formation.

We believe that the interpretation of the intervals of characteristic gamma values (Fig. 15) and the details of cycles (Fig. 16) can best be interpreted by applying the concepts of sequence stratigraphy. In sequence stratigraphy Posamentier \& Vail (1988) suggested that packages of sediment termed "systems tracts" are associated with variations in sea level and sediment supply and which are bounded by surfaces of non-deposition or erosion termed sequence boundaries.

Applying these concepts, Fig. 16 illustrates two possible sequence stratigraphy interpretations (A and $\mathrm{B}$ ) of the Altona stratigraphy. In both $\mathrm{A}$ and $\mathrm{B}$, the basal 4 meters of stratigraphy records the onlap of Precambrian basement during transgression as part of a Transgressive Systems Tract (TST). This is followed up section with the "sawtooth" gamma emission pattern that is the characteristic of shoreface successions that Farrell et al. (2013) recognized as characteristic of the Highstand Systems Tract (HST). Carbonate-rich horizons, such as those seen between 60 and 72 meters in the composite section (Fig. 15), would occur above marine flooding surfaces (representing rapid sea level rise) with clastic deposition subsequently accumulating in the accommodation space produced by the rise. The low gamma values that characterize Interval 2 (31 to 42 meters in the composite section) we interpret to record the most dolostone-rich portion of the Altona stratigraphy and in sequence stratigraphy this would be associated with maximum sea level highstand and the trapping of clastic sediment in the hinterland. Differences between the two interpretations begin with this carbonate-rich interval. In option A, the carbonate strata between 31 and 42 meters represent a change in the rate of sea level rise; with clastics temporarily unable to enter the shoreline system, and a condensed sequence produced. Above 42 meters in the stratigraphy the return to higher gamma values with the "sawtooth" pattern of the shoreface interpreted to represent the re-equilibration of sea level and sediment supply and a resumption of clastic deposition in the late stage of highstand. An alternative interpretation (option B) suggests that the highstand recorded between 31 and 42 meters includes the transgressive surface overlain by a thin transgressive interval between 40 and 41 meters in the stratigraphy, represented by rapidly increasing gamma values. As with interpretation A, above 42 meters the gamma pattern is characteristic of shoreline stratigraphy and above 76 meters a downward trend in gamma values begins as the contact with the overlying non-marine Ausable Formation, is approached. The Ausable, nonmarine sandstone, would represent deposition in a Falling Stage Systems Tract (FSST) as sea level fell and broad unconformities are generated across the shelf. The contact of the Altona with the Ausable would be a sequence boundary and it is recognized in the gamma log by the rapid transition to shorter wavelength, higher amplitude variation in gamma values.

Biostratigraphic data does not favor one interpretation over the other. Figure 16 shows the stratigraphic distribution of trilobite material collected from the Altona by Landing et al. (2009) against the Altona composite stratigraphic section. Collections of Ehmaniella spp. are found in the upper third of the unit, above the carbonaterich Interval 2. If Ehmaniella is characteristically associated with a middle Cambrian (mid-Miaolingian) trilobite fauna, then the upper third of the Altona is significantly younger than the Olenellid-bearing (Cambrian Series 2, Stage 4) lower Altona strata. While these findings do not require an unconformity in the Altona stratigraphy it is plausible that the carbonate-rich Interval 2 is related either to the production of a condensed interval or the transgressive surface. 


\section{Altona Composite Section with Gamma Log}

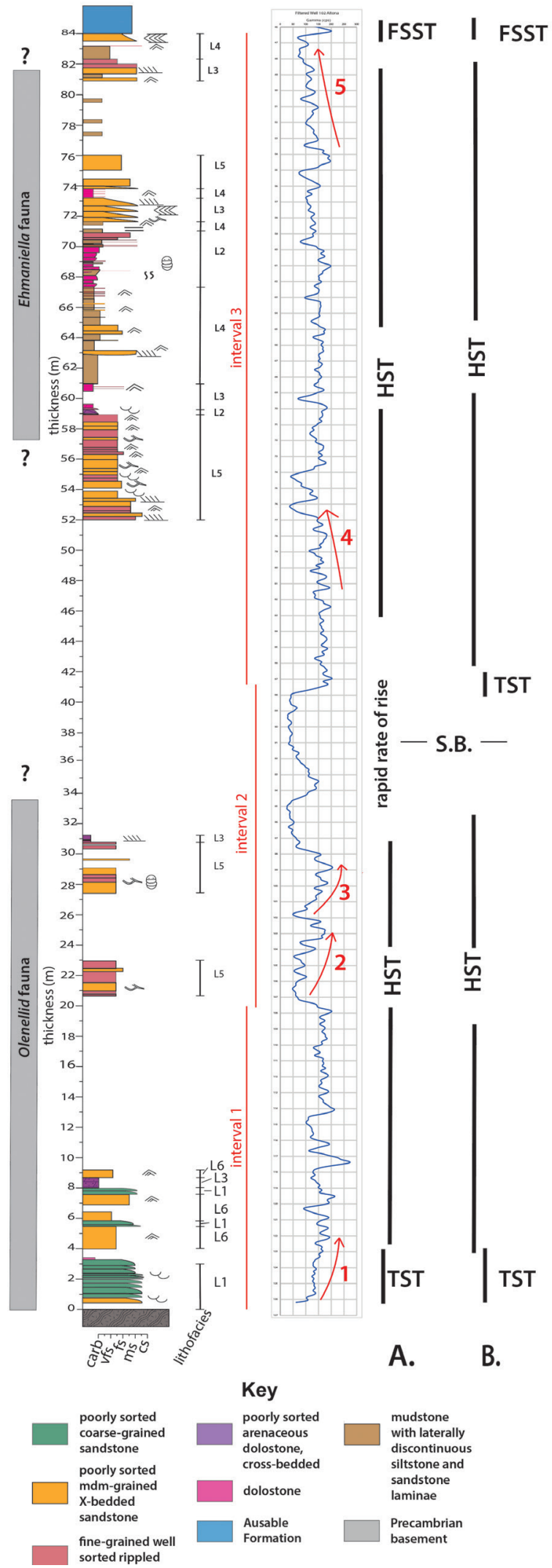

Identification of systems tracts and sequence boundaries in Potsdam Group strata is not a novel approach. In order to transcend some of the confusion regarding regional differences in stratigraphic terminology Lowe et al. (2017) applied sequence stratigraphy concepts to the study of the Potsdam Group in northern New York, southern Quebec and southern Ontario. Lowe et al. (2017) identified strata as "allounits" based on their position between sequence boundaries. These authors interpreted the Altona Formation as "Allounit 1." The present study suggests that, based on age differences between the base and top of the unit and the identification of intervals or packages of strata with distinctly different gamma emission patterns in the stratigraphy, "Allounit 1" of Lowe et al. (2017) can be subdivided into two allounits consisting of lower Altona ( 0 to 42 meters) and upper Altona (42 to 76 meters) with the overlying Ausable Formation representing a third.

\section{Compositional Analysis of Sandstones}

Altona Formation sandstones are arkose to quartz arenite in composition with variable amounts of dolomitic cement. As described in each lithofacies, several other compositions are present in the unit, including arenaceous dolostones, dolostone, and mudstone. Of the entire measured section $63 \%$ is sandstone (including dolomitic sandstone), $21 \%$ is dolostone (including arenaceous dolostone) and $16 \%$ is mudstone (with intercalated sandstone and siltstone). Table 2 and Fig. 17 summarize compositional data of the sandstones that were point counted. Using Folk's (2000) sandstone classification of the sandstones, $70 \%$ are arkose, $20 \%$ subarkose and $10 \%$ are quartz arenite.

Figure 16. Composite stratigraphic column of the Altona Formation with smoothed gamma log and interpreted sequence stratigraphy. The basal 4 meters of section show the rising gamma emissions associated with coarsening-upwards of the Transgressive Systems Tract. This is followed up section with a "sawtooth" pattern that is characteristic of shoreface successions in the Highstand Systems Tract (HST) however two intervals (red arrows 2-3) represent cycles produced by the transition from more carbonate-rich sediment (dolostones and arenaceous dolostones) to carbonate poor (arkosic sandstones). Low gamma values between 31 and 42 meters record the most dolomitic portion of the Altona stratigraphy associated with sea level highstand and the trapping of clastic sediment in the hinterland. Above 42 meters the peak in gamma values suggests that sea level and sediment supply has equilibrated and returned to clastic deposition. Red arrow 4 represents another "sawtooth" pattern of the shoreface HST, however above 76 meters begins the downward trend in gamma values as the contact with the overlying non-marine Ausable Formation is approached (Falling Stage Systems Tract FSST). The contact is recognized in the gamma log by the rapid transition to shorter wavelength, higher amplitude variation in gamma values. 
Quartz grains are monocrystalline to polycrystalline rounded to sub-rounded with quartz overgrowths. Detrital feldspar grains are both potassium rich and calcium rich and many show perthitic textures. Differences in luminescence reveal the presence of authigenic feldspar grains and overgrowths. Lithic fragments have been identified and are primarily sedimentary (dolostone, mudstone and very fine-grained siltstone) in composition. Dolostones are composed of dolomite grains which are non-planar, unimodal, and void-filling, (terminology after Sibley \& Gregg 1987). The XRD analysis on mudstones indicates that they are composed primarily of very fine silt-sized grains of orthoclase and muscovite clay.

Accessory minerals represent $1-5 \%$ abundance of detrital grains and the Altona accessory mineral suite is composed of primarily apatite, ilmenite, rutile, and zircon (Tab. 2).

\section{Origin of the red color}

As noted by Palmer \& James (1979) many of the regressive sandstones in the northern Appalachians of late lower Cambrian age are red in color (e.g., Monkton and Rome Formations). Using SEM backscatter imaging and EDS analysis the origin of the red color in the Altona was found to be the result of the formation of iron oxide-rich aluminosilicate clays by the early diagenesis of the ironrich accessory minerals (ilmenite, magnetite) in the unit (Fig. 18). These iron-rich clays are disseminated through the sandstones in early kaolinite cement interlayered with early carbonate cement (which is now dolomite). While many detrital feldspar grains appear fresh, others have undergone early diagenesis to produce in situ aluminiosilicate clays. Iron-oxides were incorporated into these early clay and carbonate cements.

\section{Provenance Analysis}

Dickinson \& Suczek (1979) pioneered the approach of plotting proportions of detrital framework grains to determine provenance types which are in turn, influenced by plate tectonic settings. An excellent review paper by Johnsson (1993) cautioned that the various controls on sandstone composition, such as recycling, weathering intensity and duration, transport processes and diagenesis, can all complicate the provenance interpretation of detrital modes. Paleoclimate models for the early Cambrian (Boucot et al. 2013) suggest that the Iapetan margin sat near the $30^{\circ}+/-$ the equator arid belt and in this climate the dominance of physical over chemical weathering would explain the fresh state of the feldspars in the Altona sandstones. Based on the textural immaturity of sand grains, which suggests limited transport and physical
A

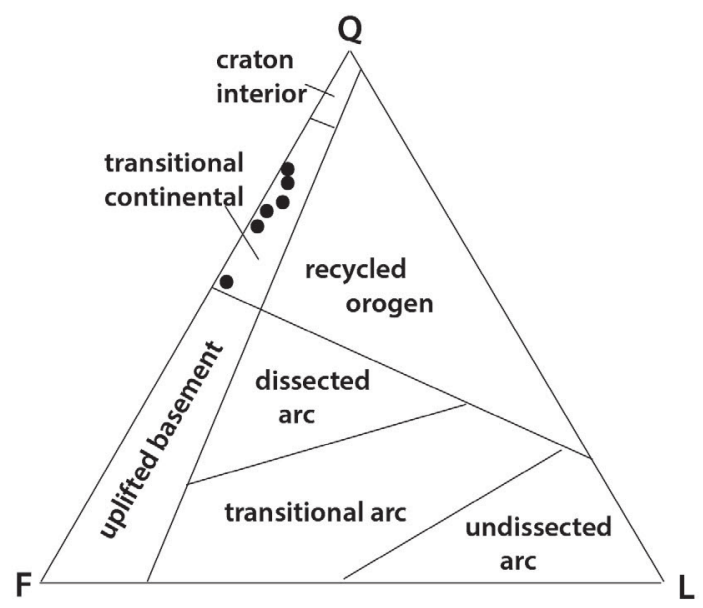

B
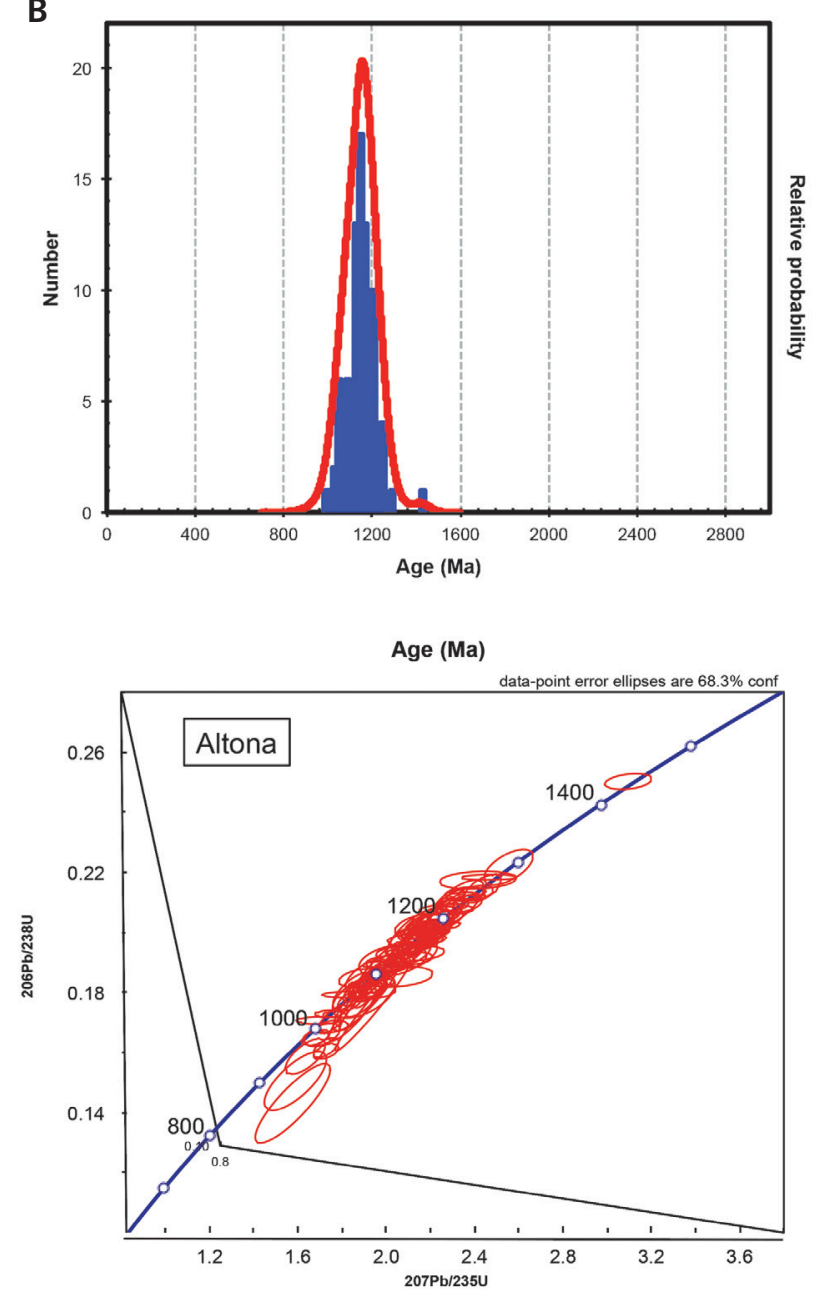

Figure 17. A - Altona modal analysis data plotted on a QFL ternary diagram (after Dickinson \& Suczek 1979). See text for discussion. • $\mathrm{B}-\mathrm{U}-\mathrm{Pb}$ detrital zircon relative abundance age spectrum from cores of zircons from the Altona Formation. This shows a single age spectrum indicating a single source of sediment of the same age between 1000 to $1300 \mathrm{Ma}$ with a peak centered at $1160 \mathrm{Ma}$. Data from Chiarenzelli et al. (2010). 
Table 2. Summary of petrography.

\begin{tabular}{|c|c|c|c|c|c|}
\hline $\begin{array}{l}\text { sandstone } \\
\text { composition }\end{array}$ & percent of samples & & & \multicolumn{2}{|c|}{$\begin{array}{l}\text { Abbreviations: } \mathrm{n} \text { - number of samples; } \\
\mathrm{Q} \text { - quartz; } \mathrm{F} \text { - feldspars; } \mathrm{L} \text { - lithic } \\
\text { fragments; } \mathrm{A} \text { - apatite; } \mathrm{I} \text { - ilmenite; } \\
\mathrm{M} \text { - magnetite; } \mathrm{R} \text { - rutile; } \mathrm{Z} \text { - zircon. }\end{array}$} \\
\hline subarkose & 20.00 & & & & \\
\hline quartz arenite & 10.00 & & & & \\
\hline sample & lithofacies & mean grain size & $\mathrm{n}$ & QnFnLn & accessories \\
\hline 092013-4 & 1 & very fine sand & 309 & $\mathrm{Q}_{19} \mathrm{~F}_{81}$ & $\mathrm{~A}, \mathrm{M}, \mathrm{R}, \mathrm{I}$ \\
\hline AF13-22 & 1 & mdm sand & 165 & $\mathrm{Q}_{92} \mathrm{~F}_{8}$ & \\
\hline AF13-23 & 1 & fine sand & 322 & $\mathrm{Q}_{36} \mathrm{~F}_{63} \mathrm{~L}_{1}$ & $\mathrm{~A}, \mathrm{R}, \mathrm{M}$ \\
\hline AF13-14 & 2 & coarse sand & 202 & $\mathrm{Q}_{77} \mathrm{~F}_{22} \mathrm{~L}_{1}$ & $\mathrm{I}, \mathrm{A}, \mathrm{R}$ \\
\hline AF13-13 & 2 & fine sand & 325 & $\mathrm{Q}_{69} \mathrm{~F}_{31}$ & $\mathrm{~A}, \mathrm{R}, \mathrm{M}$ \\
\hline MT 1-7 & 3 & dol (mdm sand) & 260 & $\mathrm{Q}_{95} \mathrm{~F}_{5}$ & $\mathrm{I}, \mathrm{R}, \mathrm{Z}$ \\
\hline AF $13-2$ & 3 & dol (mdm sand) & 230 & $\mathrm{Q}_{100}$ & \\
\hline AF13-18 & 4 & fine sand & 312 & $\mathrm{Q}_{71} \mathrm{~F}_{28} \mathrm{~L}_{1}$ & $\mathrm{I}, \mathrm{A}, \mathrm{Z}$ \\
\hline AF13-19 & 4 & fine sand & 306 & $\mathrm{Q}_{69} \mathrm{~F}_{31}$ & $\mathrm{~A}, \mathrm{I}, \mathrm{R}, \mathrm{Z}$ \\
\hline AF13-15 & 5 & fine sand & 319 & $\mathrm{Q}_{56} \mathrm{~F}_{44}$ & $\mathrm{~A}, \mathrm{I}, \mathrm{R}, \mathrm{M}$ \\
\hline AF13-18 & 6 & $\mathrm{mdm}$ sand & 312 & $\mathrm{Q}_{73} \mathrm{~F}_{25} \mathrm{~L}_{2}$ & $\mathrm{I}, \mathrm{R}, \mathrm{Z}$ \\
\hline 092013-1 & 6 & mdm sand & 330 & $\mathrm{Q}_{62} \mathrm{~F}_{38}$ & $\mathrm{R}, \mathrm{I}, \mathrm{A}$ \\
\hline
\end{tabular}

weathering intensity, and the abundance of more labile components, such as feldspar and dolostone lithics, which infer little to moderate chemical weathering, the major framework constituents of quartz, feldspar and lithic fragments were interpreted for provenance determination. As shown in Fig. 17, the sandstone compositions all plot in the "transitional continental" QFL field, a regime that describes sediment derived from fault-bounded uplifted basement such as offset segments along a rifted continental margin. The presence of low quantities of sedimentary lithics suggests the erosion of sedimentary cover on basement or possibly intraformational-derived material. The abundance of feldspar (potassium and plagioclase), the presence of both monocrystalline and polycrystalline quartz, and accessory minerals such as apatite and muscovite mica all suggest a granitic/gneissic source.

The geology of Precambrian basement of northern New York, thought to be the provenance of the Altona Formation, is complex, consisting of a wide range of metamorphic rocks that formed between 1350 and $1000 \mathrm{Ma}$ in the Grenville Cycle of McLelland et al. (1996). Detrital zircon geochronology of the Altona Formation west of this study area by Chiarenzelli et al. (2010) yielded a symmetric unimodal U-Pb peak between the ages 1000 $1300 \mathrm{Ma}$ centered at $1160 \mathrm{Ma}$ (Fig. 10B). This age is compatible with that of many metamorphic rocks in the Adirondacks, including the associated mangeritecharnockite-granite rocks (AMCG suite), which have yielded intrusion ages of $1158+/-5$ (McLelland et al. 2001). Although its perthitic feldspar-ilmentite-magnetite-apatite rich mineral suite matches that of the Altona Formation, the Lyon Mountain granite, in close geographic proximity to present day exposures of the Altona, is too young to be the its source, having yielded an age of $1040 \mathrm{Ma}$ (Valley et al. 2007).

\section{Discussion - regional implications}

A goal of this study was to combine sea level history for the Altona Formation with biostratigraphic data in order to refine correlations of the Altona Formation to other Cambrian strata along the Iapetus margin and to use such correlations to shed light on the paleogeography of the margin.

As seen in Fig. 2, biostratigraphic relationships indicate that the Altona is at least partially correlative to the Monkton Quartzite in western Vermont. The Monkton is a non-marine to tidally-influenced shallow marine prograding sandstone (Rahmanian 1981, Goldberg \& Mehrtens 1998, Maguire et al. 2018). But, unlike the Altona, which onlaps Precambrian basement, the Monkton is one unit within a shelf sequence many hundreds of meters thick; it overlies carbonates of the Salterellabearing lower Cambrian Dunham Dolostone which in turn overlies the poorly fossiliferous Cheshire Quartzite. Locally, the basal Monkton consists of sandstones and 

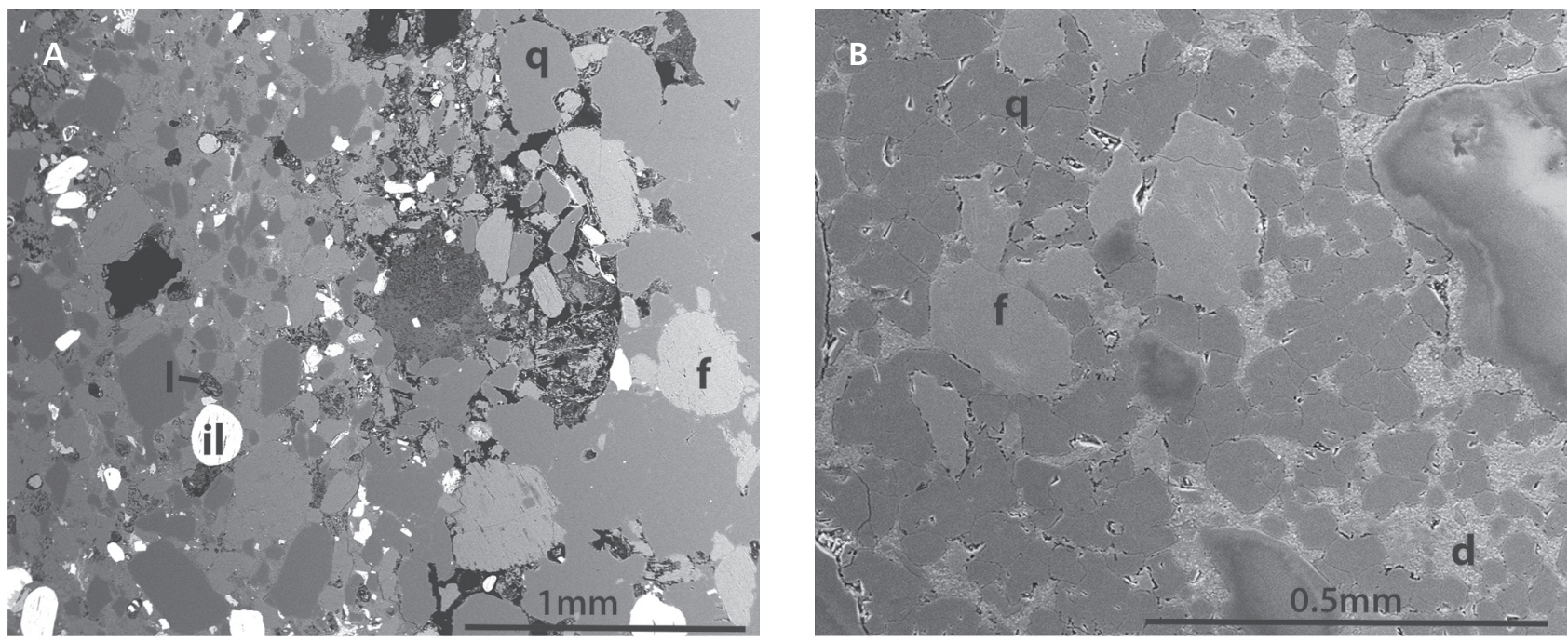

Figure 18. SEM backscatter images of two Altona thin sections. - A - quartz (q), feldspar (f), lithic fragments (1) and accessory minerals (il = ilmenite) in a sample of Lithofacies $1 . \bullet B-$ quartz and feldspar grains are sitting in a cement of intergrown carbonate and iron-rich clay, which under BSE is bright white; the intergrown fabric produces a "salt and pepper" luminescence; Lithofacies 4. Abbreviation: $\mathrm{d}$ - dolomite.

pebble conglomerates which pass upward and into more than 300 meters of mixed siliciclastic and carbonate facies, all of which were deposited during the Sauk II transgression (Goldberg \& Mehrtens 1998, Maguire et al. 2019). Thermal subsidence along the Iapetus margin produced accommodation space for this thick package of sediment and siliciclastic sediment supply kept pace or exceeded sea level, triggering basinward progradation of tidally influenced facies. Maguire et al. (2019) have interpreted the upward thinning in parasequence thickness as recording the loss of accommodation space as the rate of sea level rise slowed through Monkton deposition.

The Monkton Formation pinches out to the north on the edge of the Franklin Basin where the shales and conglomerate/breccia horizons of the Parker Slate accumulated. Analysis of the trilobite fauna within these rocks by Shaw (1958) and Palmer \& Holland (1971) documented a significant disconformity within the basinal sequence with the lowest horizons of the Parker Slate containing a lower Cambrian (Series 2, Stage 4) Olenellus fauna while upper horizons contain trilobites of the middle Cambrian (Miolingian) Bolaspidella Zone. The Monkton Formation itself contains fragmental Olenellid material (Palmer \& James 1979, Palmer personal communication). Palmer \& James (1979) suggested that this unconformity represented an Iapetus-wide event which they termed the Hawke Bay Event. According to Palmer \& James (1979) the disconformity within the Parker Slate corresponds to regressive sandstone deposition (the Monkton Formation) on the shelf.

Using sequence stratigraphy, we interpret the onlap of Precambrian basement in New York and deposition of the lower Altona Formation as having occurred during the latest, slowest stage of rising sea level that Maguire et al.
(2019) documented in the upper horizons of the Monkton Formation in western Vermont. Onlap of the Vermont shelf and deposition of the bulk of the Monkton Formation occurred earlier than in New York and the decreasing rate at which accommodation space formed in Vermont would be represented in New York by the basal 30 meters of the Altona Formation.

Karlstrom et al. (2018) presented detrital zircon dates that they used to calibrate the timing of Sauk II transgression in the Cambrian Tonto Group of the Grand Canyon (505-500 Ma). Applying the same technique to the fauna from the Potsdam Group in New York, they suggested that these strata represented also represent a short interval of time (510-505 Ma) for onlap of this portion of the eastern margin of Laurentia. The much thicker Cambrian stratigraphy in western Vermont indicates that regional variation is significant. Several hundred meters of pre-Monkton Formation stratigraphy (Dunham Dolostone and Cheshire Quartzite) suggests that Sauk I sediments were either not deposited in eastern New York, or were deposited and removed prior to deposition of the Altona Formation.

\section{Acknowledgements}

The authors wish to thank the McKinney, Atwood, and Palmer families for access to their land during the course of this study. Dave Franzi (S.U.N.Y. Plattsburgh) accompanied Brink and Mehrtens to Atwood Farm. Jeff Chiarenzelli (St. Lawrence University) graciously shared geochronologic data. Ed Romanowicz (S.U.N.Y. Plattsburgh) shared geophysical data on Altona well 1-02. Dave Lowe (University of Ottawa) read an early draft of the manuscript. Important suggestions by James Hagadorn, Carlton Brett, and the late William Kirchgasser 
greatly improved the manuscript. One of us (Mehrtens) wishes to acknowledge the many rich conversations about Potsdam Group stratigraphy and sedimentology with the late Bruce Selleck (Colgate University).

\section{References}

Abdel-Rahman, A.-F.M. \& Kumarapeli, P.S. 1999. Geochemistry and petrogenesis of the Tibbit Hill metavolcanic suite of the Appalachian fold belt, Quebec-Vermont; a plume-related and fractionated assemblage. American Journal of Science 299, 210-237. DOI 10.2475/ajs.299.3.210

Arnott, R.W. \& Southard, J.B. 1990. Exploratory flowduct experiments on combined flow bed configurations, and some implications for interpreting storm-event stratification. Journal of Sedimentary Petrology 60, 211-219. DOI 10.1306/212F9156-2B24-11D7-8648000102C1865D

Boucot, A.J., Xu, C. \& Scotese, C.R. 2013. Phanerozoic paleoclimate: An atlas of lithologic indicators of climate. Concepts in Sedimentology and Paleontology 11. Map folio. Society of Economic Paleontologists and Mineralogists, Tulsa. DOI 10.2110/sepmcsp.11

Brand, U. \& Rust, B.R. 1977. The age and upper boundary of the Nepean Formation in its type section near Ottawa, Ontario. Canadian Journal of Earth Sciences 14, 2002-2006. DOI 10.1139/e77-171

BuLl, W.B. 1972. Recognition of alluvial fan deposits in the stratigraphic record, 63-83. In RigBy, K.K. \& Hamblin, W.K. (eds) Recognition of Ancient Sedimentary Environments, Society of Economic Paleontologists and Mineralogists Special Publication 16. DOI 10.2110/pec.72.02.0063

Catuneanu, O. 2002. Sequence stratigraphy of clastic systems: concepts, merits and Pitfalls. Journal of African Earth Sciences 35, 1-43. DOI 10.1016/S0899-5362(02)00004-0

Catuneanu, O., Abreu, V., Bhattacharya, J.P., Blum, M.D., Dalrymple, R.W., Eriksson, P.G., Fielding, C.R., Fisher, W.L., Galloway, W.E., Gibling, M.R. \& Giles, K.A. 2009. Towards the standardization of sequence stratigraphy. Earth-Science Reviews 92, 1-33.

DOI 10.1016/j.earscirev.2008.10.003

Cherichetti, L., Doolan, B. \& Mehrtens, C. 1998. The Pinnacle Formation: A Late Precambrian rift valley fill with implications of Iapetus rift basin evolution. Northeastern Geology 20, 175-185.

Chiarenzelli, J., Aspler, L.B., Donaldson, J.A., Rainbird, R., Mosher, D. \& Regan, S. 2010. Detrital zircons of CambroOrdovician sandstone units in eastern Ontario and northern New York. Geological Society of America Abstracts with Programs 42(1), 118.

Clark, T.H. 1966. Chateauguay area, Chateauguay, Huntingdon, Beauharnois, Napierville and Saint Jean counties. 63pp. Geological Report. Quebec Department of Natural Resources.

Clark, T.H. \& Lewis, D.W. 1971. The Potsdam Group in southern Quebec. Geological Society of America Abstracts with Programs 3(1), 21-22.

Clifton, H.E., Hunter, R.E. \& Phillips, R.L. 1979. Depositional processes, sedimentary structures and predicted vertical sequences in barred nearshore systems, southern Oregon coast. Journal of Sedimentary Petrology 49, 711-726. DOI 10.1306/212F7824-2B24-11D7-8648000102C1865D

Coish, R., Kim, J., Morris, N. \& Johnson, D. 2012. Late stage rifting of the Laurentian continent; evidence from the geochemistry of greenstone and amphibolite in the central Vermont Appalachians. Canadian Journal of Earth Sciences 49(1), 43-58. DOI 10.1139/e11-013

Collinson, J.D. 1978. Vertical sequence and sand body shape in alluvial sequences, 577-586. In Miall, A.D. (ed.) Fluvial Sedimentology, Memoir of the Canadian Society of Petroleum Geologists no. 5.

Dickinson, W.R. \& Suczek, C.A. 1979. Plate tectonics and sandstone composition. American Association of Petroleum Geologists Bulletin 63, 2164-2182.

DOI 10.1306/2F9188FB-16CE-11D7-8645000102C1865D

Dotт, R.H. \& Bourgeois, J. 1982. Hummocky stratification; significance of its variable bedding sequences. Geological Society of America Bulletin 93, 663-680. DOI 10.1130/0016-7606(1982)93<663:HSSOIV >2.0.CO;2

Dumas, S., Arnott, R.W.C. \& Southard, J.B. 2005. Experiments on oscillatory-flow and combined-flow bed forms; implications for interpreting parts of the shallow marine rock record. Journal of Sedimentary Research 75, 501-513.

DOI 10.2110/jsr.2005.039

Elliott, T. 1986. Clastic shorelines, 143-177. In Reading, H.G. (ed.) Sedimentary Environments and Facies. Blackwell Scientific Publications, Oxford.

Farrell, K.M., Harris, W.B., Mallinson, D.J., Culver, S.J., Riggs, S.J., Wehmiller, J.F., Moore, J.P., Self-Trail, J.M. \& Lautier, J.C. 2013. Graphic logging for interpreting process-generated stratigraphic sequences from aquifer/ reservoir potential: with analog shelf to shoreface examples from the Atlantic coastal plain province, U.S.A. Journal of Sedimentary Research 83, 723-745. DOI 10.2110/jsr.2013.52

Fisher, D.W. 1955. Time span of the Theresa and Potsdam Formations in the region peripheral to the Adirondack Mountains, New York. Geological Society America Bulletin 66, 1558-1559.

Folk, R.L. 2000. Petrology of Sedimentary Rocks. 182 pp. Hemphill, Texas.

Goldberg, J. \& Mehrtens, C. 1998. Depositional Environment and Sequence Stratigraphy Interpretation of the Lower Middle Cambrian Monkton Quartzite, Vermont. Northeastern Geology and Environmental Sciences 20(1), 11-27.

Gradstein, F.M., OgG, J.G., Smith, A.G., Bleeker, W. \& LouRENS, L.J. 2004. A new geologic time scale with special reference to the Precambrian and Neogene. Episodes 27(2), 83-100.

Hagadorn, J.W. \& Belt, E.S. 2008. Stranded in Upstate New York: Cambrian Scyphomedusae from the Potsdam Sandstone. Palaios 23, 424-441. DOI 10.2110/palo.2006.p06-104r

HAmpson, G.J. 2000. Discontinuity surfaces, clinoforms, and facies architecture in a wave dominated, shoreface-shelf parasequence. Journal of Sedimentary Research 70, 325-340. DOI 10.1306/2DC40914-0E47-11D7-8643000102C1865D 
Harms, J.C., Southard, J.B. \& Walker, R.G. 1982. Structures and sequences in clastic rocks. Society of Economic Paleontologists and Mineralogists Short Course no. 9, 1-249. DOI 10.2110/scn.82.09.0000

Karlstrom, K.E., Hagadorn, J.W., Gehrels, G., Matthews, W., Schmitz, M., Madronich, L., Mulder, J., Pecha, M., Giesler, D., \& Crossey, L. 2018. Cambrian Sauk Transgression in the Grand Canyon Region Redefined by Detrital Zircons. Nature Geoscience 11, 438-443. DOI 10.1038/s41561-018-0131-7

KAY, G.M. 1942. Ottawa-Bonnechere graben and Lake Ontario homocline. Geological Society America Bulletin 53, 585-646. DOI 10.1130/GSAB-53-585

KuMARAPELI, P.S. 1993. A plume-generated segment of the rifted margin of Laurentia, Southern Canadian Appalachians, seen through a completed Wilson Cycle. Tectonophysics 219, 47-55. DOI 10.1016/0040-1951(93)90286-S

Kumarapeli, P.S., Dunning, G.R., Pintson, H. \& Shaver, J. 1989. Geochemistry and U-Pb zircon age of comenditic metafelsites of the Tibbit Hill Formation, Quebec Appalachians. Canadian Journal of Earth Sciences 23, 202-213. DOI 10.1139/e89-117

JoHnsson, M.J. 1993. The system controlling the composition of clastic sediments. Geological Society of America Special Paper 284, 1-19. DOI 10.1130/SPE284-p1

LANDING, E. 2007. Ediacaran-Ordovician of east Laurentia; geologic setting and controls on deposition along the New York Promontory region. Bulletin of the New York State Museum 510, 5-24.

Landing, E., Amati, L. \& Franzi, D.A. 2009. Epeirogenic transgression near a triple junction; the oldest (latest EarlyMiddle Cambrian) marine onlap of cratonic New York and Quebec. Geological Magazine 146(4), 552-566.

DOI 10.1017/S0016756809006013

Landing, E.S., Bowring, A., Davidek, K.L., Rushton, A.W., Fortey, R.A. \& Wimbledon, W.A. 2000. Cambrian-Ordovician boundary age and duration of the lowest Ordovician Tremadoc Series based on U-PB zircon dates from Avalonian Wales. Geological Magazine 137, 485-494.

DOI 10.1017/S0016756800004507

Leckie, D.A. \& Walker, R.G. 1982. Storm-and tide-dominated shorelines in the Cretaceous Moosebar-lowerGates intervaloutcrop equivalents of deep basin gas trap in western Canada. American Association of Petroleum Geologists 66, 138-157. DOI 10.1306/03B5ACA0-16D1-11D7-8645000102C1865D

Lowe, D., Brink, R. \& Mehrtens, C. 2015. Sedimentology and Stratigraphy of the Cambrian-Ordovician Potsdam Group (Altona, Ausable and Keeseville Formations), Northeastern NY. New York State Geological Association Guidebook Trip D-2, 1-46.

Lowe, D.G., Arnott, R.W.C., Nowlan, G.S. \& McCracken, A.D. 2017. Lithostratigraphic and allostratigraphic framework of the Cambrian-Ordovician Potsdam Group and correlations across Early Paleozoic southern Laurentia. Canadian Journal of Earth Sciences 54(5), 550-585. DOI 10.1139/cjes-2016-0151

Maguire, H., Mehrtens, C., Kim, J. \& Romanowizc, E. 2018. Plate 1: Data acquisition and processing of two subsurface wells through the Monkton Formation in Burlington Vermont;
Plate 2: Comparison of cyclicity in late Lower Cambrian gamma ray data from wells in VT and NY. Vermont Geological Survey Technical Report VG2018-7.

Maguire, H., Mehrtens, C., Kim, J. \& Romanowicz, E. 2019. Using Gamma Emissions to Identify Cycles in the Lower Cambrian Monkton Formation (NW Vermont): Implications for Identifying Sea Level Variation on the Iapetus Margin. Open Journal of Geology 9(2), 89-108.

DOI 10.4236/ojg.2019.92008

Malka, E., Stevenson, R.K. \& David, J. 2000. Sm-Nd geochemistry and $\mathrm{U}-\mathrm{Pb}$ geochronology of the Mont Rigaud stock, Quebec, Canada; a late magmatic event associated with the formation of the Iapetus rift. Journal of Geology 108(5), 569-583. DOI 10.1086/314419

McCAVE, I.N. 1984. Erosion, transport and deposition of finegrained marine sediments, 35-69. In STOw, D.A.V. \& PIPER, D.J. (eds) Fine-grained sediments: deep-water processes and facies. Geological Society Special Publications 15. DOI 10.1144/GSL.SP.1984.015.01.03

McLelland, J.L., Daly, J.S. \& McLelland, J.M. 1996. The Grenville orogenic cycle (ca.1350-1000 Ma): an Adirondack perspective. Tectonophysics 265(1-2), 1-28. DOI 10.1016/S0040-1951(96)00144-8

Mclelland, J.L., Hamilton, M., Selleck, B., Mclelland, J.M., Walker, D. \& OrRell, S. 2001. U-Pb geochronology of the Ottawan orogeny, Adirondack Highlands, New York: regional and tectonic implications. Precambrian Research 109, 39-72. DOI 10.1016/S0301-9268(01)00141-3

McKee, E.D., Crosby, E.J. \& Berryhill, H.L. 1967. Flood deposits, Bijou Creek, Colorado. Journal of Sedimentary Petrology 44, 829-851.

DOI 10.1306/74D717B2-2B21-11D7-8648000102C1865D

Mehrtens, C. \& Brink, R. 2015. Comparison of the Monkton and Altona Formations (latest Early-Middle Cambrian): Insights on the paleogeography of the Iapetus Shelf. Geological Society of America Abstracts with Programs 47, 101.

Mehrtens, C.J. \& Gregory, G. 1984. An Occurrence of Salterella conulata Clark in the Dunham Dolomite (Lower Cambrian) of Northwestern Vermont and its stratigraphic significance. Journal of Paleontology 58(4), 1143-1150.

Mount, J.F. 1984. Mixing of siliciclastic and carbonate sediments in shallow shelf environments. Geology 12(7), 432-435. DOI 10.1130/0091-7613(1984)12<432:MOSACS >2.0.CO;2

Nowlan, G.S. 2013. Report on two samples from Lower Ordovician strata in the vicinity of Rockland in eastern Ontario. Geological Survey of Canada, Paleontological Report 004-GSN-2013.

Palmer, A.R. \& Holland, C. 1971. The Cambrian of the Appalachian and eastern New England regions, eastern United States. Lower Paleozoic Rocks of the World: Cambrian of the New World 1, 169-217.

Palmer, A.P. \& James, N.1979. The Hawke Bay event: a circumIapetus event of Lower Cambrian age, 15-18. In WonEs, D. (ed.) The Caledonides in the U.S.A., Blacksburg, Virginia Polytechnic Institute and State University Memoir 2.

Pattison, S.A. 1995. Sequence stratigraphic significance of sharp-based lowstand shoreface deposits, Kenilworth Mem- 
ber, Book Cliffs, Utah. American Association of Petroleum Geologists Bulletin 79, 444-462.

DOI 10.1306/8D2B155C-171E-11D7-8645000102C1865D

Pilkey, O.H., Bush, D.M. \& Rodriguez, R.W. 1988. Carbonate terrigenous sedimentation on the North Puerto Rico Shelf, 231-250. In Doyle, L. \& Roberts, H. (eds) Carbonateclastic transitions. Developments in Sedimentology 42. DOI 10.1016/S0070-4571(08)70170-5

Posamentier, H.W. \& Vail, P.R. 1988. Eustatic controls on clastic deposition II - sequence and systems tract models, 124-152. In Wilgus, C.K., Hastings, B.S., Kendall, C.G.St.C., Posamentier, H.W., Ross, C.A. \& Van Wagoner, J.C. (eds) Sea Level Changes - An Integrated Approach: Society of Economic Paleontologists and Mineralogists Special Publication 42. DOI 10.2110/pec.88.01.0125

RaAf, J.F. de, Boersma, J.R. \& Van Gelder, A. 1977. Wave generated structures and sequences from a shallow marine succession, Lower Carboniferous, County Cork, Ireland. Sedimentology 24, 451-483.

DOI 10.1111/j.1365-3091.1977.tb00134.x

Rahmanian, V.D. 1981. Mixed siliciclastic-carbonate tidal sedimentation in the Lower Cambrian Monkton Formation of west central Vermont. Geological Society of America Abstracts with Program 12, 505.

Rey, J. \& Hidalgo, M.C. 2004. Siliciclastic sedimentation and sequence stratigraphic evolution on a storm-dominated shelf; the Lower Ordovician of the Central Iberian Zone (NE Jaen, Spain). Sedimentary Geology 164, 88-104. DOI 10.1016/j.sedgeo.2003.08.004

SANFord, B.V. 2007. Stratigraphic and structural framework of the Potsdam Group in eastern Ontario, western Quebec and northern New York State. 222pp. Ph.D. thesis, University of Ottawa, Ottawa, Canada.

SANFord, B.V. \& ARnotT, R.W.C. 2010. Stratigraphic and structural framework of the Potsdam Group in eastern Ontario, western Quebec and northern New York State. Geological Survey of Canada Bulletin 597, 1-84. DOI 10.4095/247669

SHAw, A.B. 1958. Stratigraphy and structure of the St. Albans area, northwestern Vermont. Geological Society of America Bulletin 69(5), 519-567.

DOI 10.1130/0016-7606(1958)69[519:SASOTS]2.0.CO;2

Sibley, D.F. \& GREGG, J.M. 1987. Classification of dolomite rock textures. Journal of Sedimentary Petrology 57(6), 967-975. DOI 10.1306/212F8CBA-2B24-11D7-8648000102C1865D

SLoss, L.L.1963. Sequences in the cratonic interior of North
America. Geological Society of America Bulletin 74(2), 93-113.

DOI 10.1130/0016-7606(1963)74[93:SITCIO]2.0.CO;2

Swift, D.J, Han, G. \& Vincent, C.E. 1986. Fluid processes and sea-floor response on a modern storm-dominated shelf: Middle Atlantic shelf of North America. Part 1: The stormcurrent regime, 99-119. In KNIGHT, R.J. \& McLEAN, J.R. (eds) Shelf Sands and Sandstones. Canadian Society of Petroleum Geologists Memoir 11.

Testa, V. \& Bosence, D.W. 1998. Carbonate-siliciclastic sedimentation on a high-energy, ocean-facing, tropical ramp, NE Brazil, 55-71. In Wright, V.P \& Burchette, T.P. (eds) Carbonate Ramps. Geological Society of London, Special Publication 149.

DOI 10.1144/GSL.SP.1999.149.01.05

Thомаs, W.A. 1977. Evolution of Appalachian-Ouachita salient and recesses from reentrants and promontories in the continental margin. American Journal of Science 277, 1233-1278. DOI 10.2475/ajs.277.10.1233

Trask, C.B \& Hand, B.M. 1985. Differential transport of fallequivalents and grains, Lake Ontario, New York. Journal of Sedimentary Research 55(2), 226-234. DOI 10.1306/212F867A-2B24-11D7-8648000102C1865D

TunBRIDGE, I.P. 1981. Sandy high-energy flood sedimentation some criteria for recognition, with an example from the Devonian of England: Sedimentary Geology 28, 79-95. DOI 10.1016/0037-0738(81)90058-0

Valley, P.M., Hanchar, J.M. \& Fedo, C.M. 2007. Identifying the sequence of multiple fluid events in metamorphic terranes; an example from the Lyon Mountain Gneiss, Adirondack Mountains, New York. Geological Society of America Abstracts with Programs 39, 606.

Walker, R.G. \& Plint, A.G. 1992. Wave and storm dominated shallow marine systems, 219-238. In WALKER, R.G. \& JAMES, N.P. (eds) Facies Models, Responses to sea-level change. Geological Association of Canada, Waterloo, Ontario.

Wilson, R.D. \& Schieber, J. 2014. Muddy prodeltaic hyperpycnites in the lower Genesee Group of central New York, USA: Implications for mud transport in epicontinental sea. Journal of Sedimentary Research 84, 866-874. DOI 10.2110/jsr.2014.70

YANG, B.C., Dalrymple, R.W. \& Chun, S.S. 2005. Sedimentation on a wave-dominated, open-coast tidal flat, south-western Korea: summer tidal flat- winter shoreface. Sedimentology 52, 235-252. DOI 10.1111/j.1365-3091.2004.00692.x

Appendix. Locality information in Universal Transverse Mercator (UTM) coordinates.

Atwood Farm, located in West Chazy on the Atwood Road along the banks of the Little Chazy River (UTM Zone 18: 0613737 E, $4964653 \mathrm{~N}$ ). The McKinney Farm site is located along the Military Turnpike Road (Rt. 190) from south of the road (UTM Zone 18: $0611758 \mathrm{E}, 4962606 \mathrm{~N}$ ), in drainage ditches along Rt. 190, and continuing up through the farm field on the side of Murtagh Hill. The lower Murtaugh Hill section is a stream bed exposure on the Palmer Family Maple Sugar Farm off Route 190 (UTM Zone 18: 0611739 E, 4961998 N). The upper Murtagh Hill site is located 1.5 miles up the Murtagh Hill Road off of Route 190 in a drainage ditch on the south side of the road (UTM Zone 18: 0610762 E, 4960784 N). The Purdy Mills locality is in Jericho in a stream bank off of Rand Hill Road (UTM Zone 18: 0605143 E, $4962508 \mathrm{~N})$. 